\title{
Enforcing Sympathy: Animal Cruelty Doctrine after the Civil War
}

Claire Priest

\begin{abstract}
After the United States Civil War, many states enacted laws expanding protections for animals against cruelty. This article examines the case law relating to animal cruelty in the nineteenth century, and traces how judges interpreted the animal cruelty statutes enacted after the Civil War. It provides a lens on a transformative moment when legislatures and courts recognized the suffering of animals as a distinct harm and criminalized the infliction of pain. A powerful apparatus of policing emerged to enforce this modern sensibility of sympathy. As observed in judicial decisions, the statutes repudiated earlier intent requirements, reached animal owners and conduct on private property, and in several states expanded police powers to allow warrantless arrests to protect suffering animals. The question of whether animals needlessly suffered took precedence over the earlier focus on suppressing public nuisances and common law doctrines of privacy. The animal cruelty movement provides an essential window into humanitarianism of the late nineteenth century.
\end{abstract}

At a trial in New York in 1874, Judge Josiah Sutherland delivered an extended set of jury instructions detailing the analysis required under state animal cruelty laws enacted in 1867 and 1874. The case, People v. Brunell, centered on a severely injured horse, which was made to pull a bus full of New Yorkers down Fourth Avenue. The issue was whether the proprietors and superintendent of the bus company caused the horse to be "tortured and tormented" and to suffer "great bodily or physical pain" by forcing it to work while injured (48 How.Pr. 435, 435 (1874)). As Judge Sutherland explained to the jury, there would have been no offense prior to the 1867 law. Under the older state common law, "cruelty to an animal merely upon the ground that it gave pain to the animal and for the protection or for the sake of the animal was not indictable" (ibid.). However, the new laws created new actionable offenses. They advanced the principle that "[p]ain is an evil" and "dumb creatures" should not be "unjustifiably inflicted with pain" (ibid., 437).

In a remarkable legal moment, Judge Sutherland instructed the jury to consider the case from the perspective of the horses themselves. Describing animals' dependency on humans, Judge Sutherland asked rhetorically, "Have not they a right to appeal the

Claire Priest, Simeon E. Baldwin Professor, Yale Law School, 127 Wall Street, New Haven, CT 06511. She may be contacted at claire.priest@yale.edu. For their helpful suggestions, the author would like to thank David Brion Davis, Doug Kysar, Samuel Moyn, Christopher Schmidt, Reva Siegel, and the anonymous reviewers. The author thanks Brent Salter for fantastic research assistance. Heather Richard also provided very helpful research assistance. The author would also like to thank the participants of Columbia Law School's Colloquium on Gender and Sexuality Law and Yale Law School's Animal Law Working Group. 
legislature for protection?" Judge Sutherland then stated that thousands of omnibus horses "are now pleading with you ... to carefully examine the evidence, and honestly and carefully render a verdict according to the law and the evidence, free from any prejudice or feeling" (ibid., 446 (emphasis added)). The jury found the defendants guilty. In the decades after the Civil War, new animal cruelty statutes led to similar judicial decisions in other states.

The American Society for the Prevention of Cruelty to Animals (ASPCA) was founded in 1866 in New York. It immediately succeeded in lobbying the New York legislature for the enactment of a broad 1867 anticruelty statute, which criminalized inflicting pain. Remarkably, the act vested authority in private ASPCA officers to make warrantless arrests of the statute's offenders. In the period after the Civil War, state legislatures were vastly expanding the numbers of criminal offenses over a broad range of conduct (Bishop 1892; Brickey 1995, 1139; Brown 2009, 276; Stuntz 2001, 513-14). ${ }^{1}$ Yet, the post-Civil War movement to protect animals had tremendous momentum: by 1879 , thirty-three states had enacted statutes making cruelty to animals a crime. The number increased to forty-eight states by 1900 (Leavitt 1970, 17). ASPCA officials crusaded against cruelty to animals and used their citizens' arrests powers aggressively. The ASPCA's charter included a provision requiring active police enforcement. The ASPCA reported high annual conviction rates beginning in 1866 (ASPCA, First Annual Report, 1867, 47-57). The 1870s and 1880s were a time of widespread civic participation in many reform movements and animal cruelty activism was particularly popular. Out of the 334 active humane associations in the United States in 1908, 104 focused on animal cruelty, 45 helped abused children, and 185 worked to prevent both animal and child cruelty (McCrea 1910, 14-15; Favre and Tsang 1993, 20-22). ${ }^{2}$

Within the courts, the animal welfare reformers defended their arrests in cases that tested the reach of the new statutory language and, in several states, propelled a radically new approach to animal cruelty. State court judges confronted whether to interpret the new laws conservatively as simply codifying the common law, which criminalized only cruelty constituting of breaches of the peace and conduct offending public morals, or whether, like the judge in People v. Brunell, to interpret the laws as creating a new typology of criminal offense, focusing on suffering and cruelty to the animals themselves, irrespective of the human property relationships and mens rea exclusions that had set the bounds of cruelty convictions in the past. A second line of cases tested the scope of the arrest powers the new statutes delegated to ASPCA officials.

\section{William Stunz found that:}

In 1856 , Illinois's criminal code contained 131 separate crimes. In 1874, the number had grown to 220. By 1899 it was 305; it reached 460 in 1951. ... And Illinois's numbers are fairly representative. In the past century and a half, Virginia's criminal code grew from 170 offenses to 495 (the gap is misleadingly small, since the earlier code included a large number of slavery-related crimes that have no analogue in today's code); Massachusetts went from 214 crimes (in 1860 as today, Massachusetts was a more regulated place than most) to 535. (Stuntz 2001, 513-14).

2. As a point of comparison, by 1879 , only two states, Tennessee in 1850 and Georgia in 1857 , had statutes designating wife-beating as a crime (in each case, also a misdemeanor). See 1849-1850 Tenn. Laws 301, ch. 109 (codified at Code of Tennessee $§ 10800$ (1932)); 1857 Ga. Laws 233, ch. 101 (codified at Harrison's Georgia Code Annotated § 26-1410 (1933)). For a discussion of the Protective Agency for Women and Children in Chicago, see Elizabeth Pleck, "Criminal Approaches to Family Violence, 1640-1980," Crime and Justice 11 (1989): 19-57, 43-44. 
The animal cruelty movement was a hallmark of the way that changing norms drove new legal commitments and enforcement capabilities at the end of the nineteenth century. The historian James Turner has examined how in England and subsequently the United States, rapid industrialization and urbanization led to a fundamental reconceptualization of the human place in nature leading to heightened sensitivity toward physical suffering, reflected in the rise of the animal cruelty movement (Turner 1980; Ritvo 1987). Susan Pearson's leading history of the animal cruelty movement grounds the movement's ideological basis in the sensibilities of the earlier antislavery movement and examines how animal cruelty laws served as the first legal foundation for child cruelty prosecutions, a radical police intervention into traditional family governance (Pearson 2005; Pearson 2011; Pearson and Smith 2014, 118-39). Janet Davis's The Gospel of Kindness focuses on how humanitarian reformers took the movement overseas and "envisioned their activism as a patriotic, progressive historical march from "barbarism" that reinforced American exceptionalism and paternalistic notions of American foreign policy (Ryder 1998; Beers 2006; Davis 2016, 4).

This article contributes to the literature by focusing on the doctrinal aspects of the legal regulation of animal cruelty through the end of the nineteenth century. The judicial decisions interpreting the post-Civil War animal cruelty laws provide a lens for examining an important moment when statutes created novel offenses, rooted in preventing the suffering of animals. The decisions illustrate the shifting doctrinal landscape that reflected the changing ideologies and expanded police powers of the period. The article explores the common law antecedents of animal cruelty legislation: the doctrines of domestic relations, malicious mischief, and public nuisance. It then surveys the state case law to examine the contested issues raised by the statutes and how judges interpreted the statutes as modifying the common law in several states.

To date, the most comprehensive studies of the judicial decisions on animal cruelty were written in the nineteenth century. Oscar L. Quinlan's 1894 article, "Have Animals Rights?" offers the most detailed account of the case law. Importantly, however, Quinlan approached the subject from a highly skeptical vantage point, revealing that his analysis was rooted in a belief that "animals probably do not and cannot suffer nearly as much as is generally believed. ... As the brutes have not man's higher consciousness, so they have not his capacity for suffering" (Quinlan 1894, 162). Quinlan concludes that the animal cruelty statutes must be interpreted as protecting against harms to the public, and not as recognizing a right in animals to be free from suffering. Joel Prentiss Bishop's treatise of 1873 includes a section on the crime of animal cruelty, but examines only a small number of judicial decisions (Bishop 1873, 676-94, §§ 1093-1118). More recently, Susan Pearson discusses the framework of common law judicial doctrine and the interpretation of the new animal cruelty statutes in her work (Pearson 2011, 77-82).

This article relies on fifty-five judicial decisions on animal cruelty, primarily from the period 1867 to 1897 . Judges interpreting the new animal cruelty statutes faced the issues of whether the new statutes repudiated the common law requirements of a malicious intent, a breach of the peace, and the special dispensations given to owners and on private property.

Examining the cases shows that, first, some early cases challenged ASPCA arrests on the basis of common law privacy, a doctrine judges invoked to hold that conduct on private property was outside of the jurisdiction of the courts. In New 
York, judges interpreted the new statutes as bestowing ASPCA officials with expansive arrest powers warranting the avoidance of common law privacy as a defense. Second, although under the common law, the principal animal cruelty prohibition was the offense of "malicious mischief," which penalized violence to animals propelled by malice, judicial decisions interpreted the new animal cruelty statutes as eliminating malicious intent as a requirement of the offense. Under the animal cruelty laws, criminal conviction rested on the issue of whether cruelty and needless suffering had been inflicted, irrespective of whether the animal's owner was the perpetrator, and irrespective of whether the perpetrator's conduct was driven by malice. Third, judges struggled with whether the new animal cruelty laws, at base, expanded the umbrella of conduct that constituted a breach of the peace. Under a conservative reading, a "breach of the peace" was necessary for a conviction, but more forms of animal cruelty could constitute the offense. Notably, judges in New York, Arkansas, and a few other states interpreted the statutes as going further, as criminalizing cruelty to animals irrespective of any public harm that might serve as justification. As the Supreme Court of Arkansas stated in Grise v. State in 1881, the animal welfare laws "seem to recognize and attempt to protect some abstract rights in all that animate creation, made subject to man by the creation, from the largest and noblest to the smallest and most insignificant. ... So construed, this class of laws may be found useful in elevating humanity, by enlargement of its sympathy with all God's creatures, and thus society may be improved" (37 Ark. 456, 458-59 (1881)).

The importance of the post-Civil War animal cruelty movement has gained recognition in history departments, but less so among legal historians. Putting the doctrinal history of the movement into the foreground is a step toward giving its radical legal transformation-toward a focus on sympathy, rooted in an abhorrence of cruelty and pain-the attention it deserves. As Susan Pearson has shown, the animal cruelty laws quickly influenced the law relating to child cruelty. Linda Gordon notes that the "legal basis for prosecuting animal abusers existed when there were no such means against child abusers [or violent spouses]" which was an "irony appreciated by 1870 s reformers" (Gordon 1988, 34). The historian Elizabeth Pleck quotes supporters of domestic violence legislation in England who insisted that Parliament should extend "the same protection to defenseless women as they already extended to poodle dogs and donkeys" (Pleck 1987, 64). The impact of the animal cruelty movement was possibly broader. Historians of human rights laws have often identified their origins in legal recognition of "sympathy" inherent in the antislavery and anti-slave trade campaigns of the nineteenth century (Davis 1966; Martinez 2012). ${ }^{3}$ Within this literature, the animal cruelty movement is often overlooked.

The post-Civil War animal cruelty movement in the United States was significant in that it applied the sympathetic sensibilities of the antislavery movement to a ubiquitous form of property relations both in states that historically had relied on free labor markets as

3. The historian Samuel Moyn asserts that modern human rights did not emerge until the 1970s, yet he acknowledges that "during the Enlightenment ... a new secular version of the old Christian imperative of pity made more familiar appeals to 'humanity' possible, first by shifting the meaning of the term so that it now typically implied feeling others' pain. Though this new culture of sympathy had its own boundaries, it clearly did help construct new norms opposed to depredations against the body like enslavement and violence in punishment" (Moyn 2010, 19-20). 
well as those that had enforced slavery. Equally important, the new animal cruelty laws drew from the temperance laws of the 1850s to include enforcement mechanisms, such as police mandates and warrantless arrests, that vastly expanded the reformers' impact. It represented a movement, much like temperance, where humanitarian advocates were given powers of law enforcement to bring about a rapid change in norms and practices, primarily to advance greater order in urban spaces. Yet, the judicial decisions in which animal cruelty arrests were challenged and defended in court reveal the scope of the movement's impact, particularly in the handful of states where judges departed from the common law to create a new typology of offense rooted in preventing pain and suffering.

Part I analyzes the eighteenth and nineteenth century common law regulation of cruelty in domestic relations and the prohibitions on cruel conduct that violated the public morals or constituted a breach of the peace. Part II describes the enactment of the new anticruelty laws and the ASPCA's early enforcement regime in New York. Part III examines the case law in the late nineteenth century, and illustrates how judges interpreted the new statutes as recognizing cruelty as a harm, irrespective of limitations on prosecutions that applied in the past.

\section{ANTEBELLUM CRUELTY REGULATION}

Legal developments in the area of animal cruelty are best understood with reference to the nineteenth century law of domestic relations, which placed some bounds on the authority of heads of households to correct and chastise members of the household. In contrast, traditionally longstanding common law doctrine prevented cruelty to animals only to the extent that the conduct was determined to be an offense to the public or a breach of the peace. This part describes the traditional common law approach toward cruelty within the household and contrasts it with the eighteenth-century expansion of prosecution of cruelty characterized as implicating the public. The following parts, then, will describe the early stages of the transformation of this legal framework after the Civil War.

\section{Regulation of Violence in the Household: Chastisement of Wives, Children, and Servants}

Under the common law doctrine of the eighteenth and early nineteenth centuries, the head of the household, in his role as husband, father, and master, traditionally had authority to "chastise" or "correct" his spouse, children, and domestic workers. ${ }^{4}$ The authority of the head of the household was not absolute: He generally held only the limited right to impose "moderate correction," which meant, in a very fact-specific sense, correction suited to the misbehavior in question. Courts, however, often avoided intervening in all but the most egregious cases of domestic violence, typically upholding a family governance model that analogized the head of the household to a "court"

4. The principal justification for this authority was that, since the husband was held liable for his dependents' acts and misdeeds, he (almost necessarily according to the common law) should have the right to govern and punish them to keep them in line. See $1 \mathrm{William}$ Blackstone, Commentaries * 432. 
holding primary "jurisdiction" over a case. State courts were available to hear "appeals" from the family government, but gave the deference normally accorded a lower court. In describing a parent's right to chastise his child, Tapping Reeve, author of America's first family law treatise in 1816, emphasized that "[T]he parent ought to be considered as acting in a judicial capacity when he corrects, and, of course, not liable for errors of opinion" (Reeve 1862, 420). Moreover, if a parent's motives were proper, the court would not second-guess the level of punishment inflicted. Reeve, stated, for example, that "although the punishment should appear to the triers to be unreasonably severe, and in no measure proportioned to the offense, yet, if it should also appear that the parent acted conscientiously, and from motives of duty, no verdict ought to be found against him"(Reeve 1862, 420).

The common law rules regarding the right of chastisement reflected a household hierarchy implicitly recognized by the common law in which the husband was head, with his wife, then domestic employees and children, then property such as slaves (in America) and animals, beneath him. By the late eighteenth and early nineteenth centuries, contemporary legal thinkers such as Blackstone and Tapping Reeve denied that courts widely recognized the right of spousal chastisement. ${ }^{5}$ From a very early stage, however, courts expressed a special reluctance to intervene in marital affairs. At common law, wives had no civil remedy against their husbands. As explained by Reeve: "The nature of the connection between [husband and wife] is such, that no atrocity of conduct ... can give either a right to an action to recover damages" (Reeve 1862, 141).

When faced with domestic violence claims, judges routinely invoked the common law privacy doctrine, which holds that family relations are a "private" matter into which courts should not intrude (Grossberg 1985, 6, 11; Siegel 1996, 2132-40). As an example, in State v. Rhodes, an 1868 North Carolina Supreme Court decision, the judge ruled against convicting Rhodes for assault and battery of his wife, reasoning:

[T] he ground upon which we have put this decision, is not, that the husband has the right to whip his wife much or little; but that we will not interfere with family government in trifling cases. ... We will not inflict upon society the

5. Cf. Bradley v. State, 1 Miss. (1 Walker) 156, 158 (1824) (recognizing right of "moderate chastisement"); State v. Black, 60 N.C. (Win.) 262, 262 (1864) (permitting force necessary to "control an unruly temper"). Historically the common law had recognized a husband's right to chatise or correct his spouse. According to William Blackstone:

THE husband also (by the old law) might give his wife moderate correction. For, as he is to answer for her misbehaviour, the law thought it reasonable to intrust him with this power of restraining her, by domestic chastisement, in the same moderation that a man is allowed to correct his servants or children; for whom the master or parent is also liable in some cases to answer. But this power of correction was confined within reasonable bounds, and the husband was prohibited to use any violence toward his wife, aliter quam ad virum, ex causa regiminis et castigationis uxoris suae, licite et rationabiliter pertinet.

1 William Blackstone, Commentaries * 432. See also Reva B. Siegel, "'The Rule of Love': Wife Beating as Prerogative and Privacy," Yale Law Journal, 105 (1996): $2122-29$ (discussing history of husbands' right of chastisement).

Blackstone continues, however, "But, with us, in the politer reign of Charles the second, this power of correction began to be doubted: and a wife may now have the security of the peace against her husband; or, in return, a husband against his wife." 1 Blackstone, Commentaries $* 433$. 
greater evil of raising the curtain upon domestic privacy, to punish the lesser evil of trifling violence (61 N.C. (Phil. Law) 453, 459 (1868) (emphasis added)).

This language from the Rhodes opinion, which is similar to that of many other contemporary opinions (see, for example, State v. Black, 60 N.C. (Win.) 262, 267 (1864)), suggests broad acceptance of the idea that family relationships were inherently private and that, as a normative matter, judges should protect family privacy and severely limit intervention by government in family affairs. Again, according to the Rhodes court, "raising the curtain upon domestic privacy" in order to prevent violence between spouses was a greater evil than punishing "trifling" violence.

In contrast to the more ambiguous legality of the martial chastisement right during the late eighteenth and early nineteenth centuries, the common law clearly recognized fathers' right to chastise their children and those domestic employees in relation to which he stood, by consent, in loco parentis (Pleck 1987, 34-35). ${ }^{6}$ With respect to children, for example, according to Reeve:

The parent has a right to govern his minor child; and, as incident to this, he must have the power to correct him. The maxim is, that he has the power to chastise him moderately. ... The parent is bound to correct a child so as to prevent him from becoming the victim of vicious habits, and thereby proving a nuisance to the community (Reeve 1862, 420).

The key factor in determining whether a father's corporal punishment was "moderate" was to examine his intent in administering punishment. A jury determination that the father acted with a bad intent, an unleashed and irrational temper, malo animo, potentially opened the door to government enforcement of the criminal laws for assault (Reeve 1862, 420-21). In general, however, common law regulation of violence toward children and domestic employees was modest (Pleck 1989, 34).

As property, slaves and animals had, respectively, the most inferior legal status within the household hierarchy. Slaves were almost universally characterized under state law as subject to the absolute authority of their masters. Indeed, physical chastisement was the normal course in many master/slave relations (Morris 1996, 182-208; Tushnet 2003). As the legal historian Lea VanderVelde has shown, although the master's right of chastisement in higher status free labor contexts was taken away by the 1830 s and 1840 s, the historical evidence suggestion that there was "an accompanying

6. For cases, see, for example, Johnson and Wife v. State, 21 Tenn. 229 (2 Hum. 283) (1837) appended to Saunders \& Martin v. Turbeville, 21 Tenn. 220 (2 Hum. 272) (1840) (upholding, in general, parents' right to chastise their children with moderation); Pendergrass v. State, 19 N.C. 365, 366-68 (1837) (upholding the right of a teacher or parent to chastise a child moderately with an instrument). According to Reeve, when the master stood in loco parentis, he held the right to administer "moderate corporal correction ... for disobedience to his lawful commands, negligence in his business, or for insolent behavior" (Reeve 1862, 534). Although this right was "confined to apprentices and menial servants" in which he stands "in loco parentis. ... He has full authority over all slaves, apprentices, and others living with him, who are subject to the control of a parent or guardian" (ibid., 534). Reeve's treatise distinguishes the right of heads of households to chastise domestic employees and children, from the lack of right over wives in this respect. According to Reeve, "I much doubt whether the law of England would indulge the husband in correcting a wife on the same ground that it would warrant his correction of a servant or a child" (ibid., 141). 
entrenchment of beatings for lower-order labor statuses, such as slaves and sailors" (Vandervelde 2016, 746). Commonwealth v. Turner, a case decided by the General Court of Virginia in 1827, was exemplary in denying jurisdiction in a case where the master was found to have "wilfully and maliciously, violently, cruelly, immoderately, and excessively beat, scourge[d] and whip[ped]" his slave (26 Va. 678, 678 (1827)). The court held that it had no basis for jurisdiction over the case, either under statutory or common law authorities (ibid.).

As early as the late eighteenth century, some colonies enacted statutes intended to protect slaves from the worst forms of cruelty. Judicial opinions of the early nineteenth century reveal that some states based their law of cruelty toward slaves loosely on the common law regulation of treatment of domestic employees, that is, in theory, prohibiting cruelty motivated by malo animo (see, for example, James v. Carper, 36 Tenn. 397, 397, 402, 404 (1857)). According to Thomas Morris, however, even in these states, the law on the books and the law as enforced were extremely different (Morris 1996, 183$85)$. It is fair to say that cruelty toward slaves within the household, unless the slave was severely maimed or killed, which was prohibited, typically occurred free from prosecution (see James v. Carper, 36 Tenn. 397 (1857); Wilson v. State, 29 Tex. 240 (1867)).

\section{Common Law Regulation of Public Cruelty to Animals: Public Nuisance and Malicious Mischief Doctrines}

The first colonial animal cruelty law was included in the 1641 Massachusetts Body of Liberties, which states: "[N]o man shall exercise any Tyranny or Cruelty towards any Bruit Creatures, which are usually kept for the use of man" (General Laws and Liberties of the Massachusetts Colony 1672, 39). Evidence of its enforcement is lacking (Leavitt 1970, 13-17. Outside of Puritan Massachusetts, in the seventeenth, eighteenth, and for much of the nineteenth century, violence to animals was accepted as a natural feature of life (see Ryder 1989, 55-58).

Animals had a far greater presence in cities in the nineteenth century. Slaughterhouses were a much more central part of city life than today: prior to widespread use of refrigerated train cars in the 1870s and 1880s, they were more centrally located near marketplaces and cattle were brought live through town on their way to being killed (see Cronan 1991, 208-12). Cock-fighting, bear-baiting (involving dogs and bears), bull-baiting, and fox hunting were favorite forms of entertainment for the wealthy (see E.S. Turner 1964; Carson 1972, 63-94). Vivisections (dissection or experimentation on live animals, typically without the use of anesthesia) were a popular upper-class social and educational event in the eighteenth century, even though the animal subjects would wail in pain throughout experiments (E.S. Turner 1964, 45; Turner 1980; Lansbury 1985; Richards 1987, 125, 136; Ryder 1989, 56). Most legal limitations on animal owners' use and enjoyment of animals on their property were inconceivable.

Concern for public order, social control, and decency propelled nineteenth century judges to apply various common law rules to prohibit cruelty to animals. Initially, cruelty to animals was prosecuted incidentally, as merely one of many possible types of public harms. Animal cruelty was not singled out as a particularly egregious kind of 
conduct. Indeed, existing state law typically ran against efforts to prosecute. Remarkably, Blackstone's Commentaries of the 1780s makes no mention of animal cruelty in its long and detailed list of offenses indictable as nuisances, which included broken bridges and obstructed rivers; keeping hogs in the city; disorderly inns, gaming houses and stage plays; lotteries; the making of fireworks; eavesdroppers; and common scolds (women disturbing the peace with noisy and abusive behavior) (4 Blackstone, 167-70).

The 1788 Pennsylvania Supreme Court case of Respublica v. Teischer was an early case upholding a conviction for "maliciously, wilfully, and wickedly killing a horse" (1 U.S. 335 (1788)). Justice M'Kean explicitly conceded that there were no state precedents for prosecuting cruelty to animals. Yet, he held that "whatever amounts to a public wrong may be made the subject of an indictment" (ibid., 337). In affirming the lower court's conviction, Justice M'Kean emphasized the breadth of offenses indictable as public harms, listing "the poisoning of chickens; cheating with false dice; fraudulently tearing a promissory note, ... [b]reaking windows by throwing stones at them, ... and the embezzlement of public monies." He concluded that each of these "have, likewise, in this State been deemed public wrongs, for which the private sufferer was not alone entitled to redress" (ibid., 338). Thus, in contrast to singling out animal cruelty for special attention, the judge grounded his decision in the breadth of the conduct encompassed by the public harm offense (that is, the offense fit in under a very wide umbrella).

Following Respublica $v$. Teischer, regulation of behavior in public spaces expanded dramatically over the eighteenth and nineteenth centuries. Arrests for breaches of the peace, vagrancy, drunkenness, assembling, and other morals violations were commonplace (Novak 1996, 148-89; Goluboff 2016). As the historian William Novak has described, "public nuisance law was one of the most potent regulatory weapons in the common law arsenal, subjecting an offender to bold public remedies" (Novak 1996, 158). Perhaps not surprisingly, in the early decades of the nineteenth century, indictments for cruelty to animals in a public place appear in various state court records. U.S. v. Jackson, an 1834 case from Washington D.C., is a typical public nuisance conviction for animal cruelty. The indictment described the offense as: "[I]n the public street ... in view of the said streets and dwellings and said citizens," Daniel Jackson "did cruelly with clubs and stones, beat, strike and grievously wound and kill a certain cow ... to the terror and disturbance of the said citizens" (26 F. Cas. 555, 555 (1834)). The judge in the case refused to quash the indictment on the grounds that Maryland common law did not recognize cruelty to animals as an offense, and the Virginia cases were "founded upon the peculiar qualities of slavery." In contrast, the court instructed the jury that the offense in question was cruelty as a public nuisance (see United States v. Logan, 26 F. Cas. 990 (1821)).

With regard to the slavery cases, it appears that the public nuisance doctrine as it related to cruelty to slaves paralleled the doctrine as it related to animals. The cases often compared the two contexts. The 1827 Virginia case of Commonwealth $v$. Turner, for example, reaffirmed the authority of a master over his slave within the context of the household, but held that public cruelty to slaves and animals could be punished under public nuisance doctrine. According to the court: 
When the Courts recognize the power to punish one who should take his slave into the market place, and there violently beat him, it is not because it was a slave who was beaten, nor because the act was unprovoked or cruel; but because ipso facto it disturbed the harmony of society; was offensive to public decency, and directly tended to a breach of the peace. The same would be the law, if a horse had been so beaten. And yet it would not be pretended, that it was in respect to the rights of the horse, or the feelings of humanity, that this interposition would take place (26 Va. 678, 680 (1827); see also Francione 1995, 110-11).

Similarly, State v. Hale, decided by the Supreme Court of North Carolina in 1823, stated that:

The common law has often been called into efficient operation, for the punishment of public cruelty inflicted upon animals, for needless and wanton cruelty inflicted by masters on their slaves, and for various violations of decency, morals and comfort. Reason and analogy seem to require that a human being, although the subject of property, should be so far protected as the public might be injured through him (9 N.C. 582, 585 (1823) (emphasis added)).

These cases illustrate clearly that slaves, like animals, were protected only indirectly, that is, when their owners' conduct constituted a breach of the peace or other public harm.

A second doctrine under which animal cruelty was punished under eighteenth century common law was malicious mischief, defined as malicious destruction of someone else's property. Blackstone's Commentaries notes that malicious mischief is an "injury to private property, which the law considers as a public crime" (4 Blackstone, 243). ${ }^{8}$ Blackstone defines it as a destruction of someone else's property, not for indirect profit, but out of a "spirit of wanton cruelty, or black and diabolical revenge. In which it bears a near relation to the crime of arson; for as that affects the habitation, so this does the other property, of individuals" (ibid.). Throughout the American states, the requirements of the crime of malicious mischief as applied to animal property were initially uniform: the prosecution had to show a "malicious" or "wicked" intent, and the maiming, or killing of someone else's animal property. ${ }^{9}$ Just as in the case of cruelty toward children, the crime was constituted by the malicious

7. See also Commonwealth v. Lee \& Bledsoe, 60 Ky. 229 (1860) (applying similar reasoning). State v. Hale differed from Commonwealth v. Turner, however, in that it sustained an indictment for public cruelty. Judge Taylor's concern was not simply that the public might be brutalized by the violence, but also that allowing random beatings of slaves would "awaken the resentment" of slaves generally.

8. Although cruelty to animals was not traditionally included under malicious mischief doctrine at common law, its application was expanded in the United States and cruelty to animals came to exemplify the offense. See, for example, State v. Beekman, 27 N.J.L. 124 (1858) (The offense "has received [in the United States] a far more extended interpretation than has been attached to it in England.").

9. See, for example, State v. Council, 1 Tenn. 305 (1808) (Tenn.Super.L. \& Eq.); State v. Briggs, 1 Aiken (Vt.) 226 (1826); Davis v. Commonwealth, 30 P. 421 (1858); Wright v. Georgia, 30 Ga. 325 (1860); State v. Avery, 44 N.H. 392 (1862); Fairfax Branch v. State, 41 Tex. 622 (1874); Brown v. State, 26 Ohio St. 176 (1875). 
state of mind in which the acts were done. According to an 1825 New York case, People v. Smith, for example:

[S] uch an act discovers a degree of moral turpitude, dangerous to society; and for their [sic] security, ought to be punished criminally. It is an evil example of the most pernicious tendency, inasmuch as the act is an outrage upon the principles and feelings of humanity. The direct tendency is a breach of the peace. What more likely to produce it, than wantonly killing, out of mere malice, a useful domestic animal? (5 Cow. 258, 258 (1825)). ${ }^{10}$

The New York court cited similar cases from Pennsylvania and Massachusetts and emphasized that "[i]t cannot be expected, that the mere liability to damages, will operate on a mind so depraved. ... The perpetrator may be insolvent; and thus gratify his malice with impunity, if there is no redress otherwise than by civil action" (ibid., 259). ${ }^{11}$ Initially, however, justifications, such as that the animal was killed because it had damaged the offender's property, sufficed as complete defenses (see Wright v. Georgia, 30 Ga. 325 (1860); Duncan v. State, 49 Miss. 331 (1873); Darnell v. State, 6 Tex. App. 482 (1879)).

\section{Early Anticruelty Statutes}

In 1828 , New York became the first state to enact an anticruelty law applying to animals. According to the statute:

Every person who shall maliciously kill, maim, or wound any horse, ox, or other cattle, or sheep, belonging to another, or shall maliciously and cruelly beat or torture any such animal, whether belonging to himself or to another, shall upon conviction, be adjudged guilty of a misdemeanor. ${ }^{12}$

Nineteen other states enacted similar statutes by 1865 (Leavitt 1970, 17). ${ }^{13}$

Although the language of the New York statute might suggest a generalized concern with animal abuse, initially courts in New York and other states widely interpreted the statutes as legislative reiterations of the preexisting common law rules of malicious

10. Cited in Kilpatrick v. People, 5 Denio 277, 280 (1848). Davis v. Commonwealth reasoned similarly that:

[C]ruelty to animals is in itself of evil example and a public offence. It is not only an assault on life, which, though that of a dumb beast, is nevertheless not beneath the protection of law, but it is also plainly indicative of a heart regardless of social duty, and fatally bent on mischief ... (30 Pa. 421, 424 (1858)).

11. The court referred to Respublica v. Teischer, 1 U.S. 335 (1788) (Pennsylvania case holding actionable maliciously, wickedly, and wilfully killing a horse), Commonwealth v. Taylor, 5 Binn. 277 and Commonwealth v. Leach, 1 Mass. 59 (1804) (poisoning a cow).

12. N.Y. Rev. Stat. Tit. 6, 26, § 26 (1829).

13. Massachusetts (1835); Connecticut (1838); Wisconsin (1838); New Hampshire (1842); Missouri (1845); Virginia (1848); Iowa (1851); Minnesota (1851); Kentucky (1852); Vermont (1854); Texas (1856); Rhode Island (1857); Tennessee (1858); Kansas (1859); Washington (1859); Pennsylvania (1860); Nevada (1861); Idaho (1864); and Oregon (1864). 
mischief and public nuisance. The first sentence in the statute above-prohibiting maliciously killing, maiming, or wounding an animal "belonging to another"-for example, was interpreted as a legislatively enacted version of the malicious mischief prohibition (see State v. Beekman, 27 N.J.L. 124 (1858); State v. Smith, 21 Tex. 748 (1848)). The second sentence-extending prosecution to those who "maliciously or cruelly beat or torture any such animal" whether belonging to himself or anotherwas viewed as a legislatively-enacted version of public nuisance law (McCrea 1910, 34; Commonwealth v. Tilton, 49 Mass. 232 (1844)). These statutes were therefore applied in a manner that excluded animal cruelty by the animal's owner unless (1) the owner "maliciously or cruelly beat or torture[d]" the animal and (2) did so in public. Thus, despite the existence of animal anticruelty statutes in increasing numbers of states, there was not at this time, for example, widespread suppression of cock-fighting, bull-baiting, or private hunting and other forms of entertainment relying on cruelty to animals (McCrea 1910, 61-62). ${ }^{14}$ Even though these activities often involved a clear public dimension, judges viewed them as off-limits because they occurred on private property.

An animal cruelty case from Texas, State $v$. Smith (1858), reveals that in denying that anticruelty provisions applied to violence occurring on private property, courts invoked the same "privacy" rationale that was applied in domestic violence cases. As mentioned above, the privacy rationale immunized heads of households from criminal prosecution and civil suit on the theory that courts' interference with private domestic relations was a greater harm to society than the conduct itself (Grossberg 1985, 6, 11; Siegel 1996). State v. Smith required an interpretation of Texas's first animal anticruelty statute, enacted in 1856. The statutory language was more expansive than New York's 1828 statute in that, "any person," whether the owner or not, could be prosecuted, and for abuse of "any dumb animal," not just the domesticated animals listed in the New York statute (State v. Smith, 21 Tex. 748, 748 (1858)). Still the Supreme Court of Texas quashed an indictment of the lower court on grounds that the defendant owned the animal that he beat to death (not relevant from the language of the statute). The court reasoned that prosecutions for animal cruelty were an invasive form of government intervention into private matters that would bring disharmony to the community. According to the court:

It is not the policy of the law, in this country, to establish an espionage over the domestic concerns, by which every intermeddling, malicious neighbor may have an excuse, on the ground of humanity, to thrust his own ideas of the propriety or morality into the private affairs of others around him. The encouragement it would give to make humanity the cloak of malice and envy,

14. Cf. Commonwealth v. Tilton, 49 Mass. 232, 235 (1844):

As being barbarous and cruel, leading to disorder and danger, and tending to deaden the feelings of humanity, both in those who participate in it, and those who witness it, [cock-fighting] appears to us to stand on the same footing with bull-fighting, bear-baiting, and prizefighting with fists or dangerous weapons, all of which, we think, would be considered as unlawful games or sports. We are strongly inclined to the opinion, that a place, opened as a place of public or general resort for these purposes, especially for hire, would be held a nuisance at common law; and it seems not the less unlawful, when practised at a place authorized by law for all persons to resort to. 
would be a worse evil, by producing dissensions in the community, than any amount of cruelty to dumb animals, known to exist (ibid., 751 (emphasis added)).

After the Civil War, the animal welfare movement began campaigning for animal cruelty laws that treated the infliction of pain as a crime, irrespective of the limitations, such as privacy and ownership, that had previously existed under the common law.

\section{The Animal Welfare Movement's Rise}

The great transformation in popular conceptions of animals can be attributed to the widespread acceptance that sentience is universal to all living beings, and that infliction of pain is a normative and ethical problem. In the nineteenth century, as pain entered the realm of ethics, many social institutions that functioned through domination were considered in need of reform. Historians have recognized an almost simultaneous development of antislavery sentiment, advocacy for animal welfare, diminished use of torture, and hostility to the use of corporal punishment to discipline children, prisoners, sailors, and women (Turner 1980, 34-37; Glenn 1984, 3-4). The first three decades of the nineteenth century was the period of the emergence of the modern prison system-which removed execution from the public streets (Foucault 1979, 3-69, 293-308). In keeping with broader trends, the animal welfare movement emerged first in England, where William Wilberforce helped to found the Royal Society for the Prevention of Cruelty, which gained official recognition in 1840 .

The dominant presence of slavery greatly shaped the contours of humanitarian movements in the United States, even more so than in Britain. The antislavery movement gained force in the early nineteenth century, leading to Garrison's open advocacy of "immediate emancipation" in 1830 (Walters 1976, xi). The historian Elizabeth Clark has emphasized that in the thirty years before the Civil War, abolitionists focused on violence as a primary harm in the master-slave relationship (Clark 1995, 463-93). As Clark has compellingly described, by basing their "claim to rights on the very capacity to suffer and feel pain," abolitionist rhetoric helped evolve humanitarian sentiments toward sympathic responses to physical cruelty (Clark 1995, 487). To Clark, by the time of the Civil War, "legal standards came to incorporate (albeit imperfectly) the idea that to be free of physical coercion and deliberately inflicted pain was an essential human right" (Clark 1995, 463). Susan Pearson's The Rights of the Defenseless incorporates Clark's theory into a broader account of the changing sensibilities driving the post-Civil War animal welfare movement (Pearson 2011, 111-15).

Humanitarian discourse in the United States ran parallel to Jeremy Bentham's utilitarianism in England. Jeremy Bentham's Introduction to the Principles of Morals and Legislation of 1780 presented a simple pleasure/pain calculus, which he viewed as applying to animals and to humans equally. In what, perhaps, remains to this day the central justification for better treatment of animals and animal rights, Bentham asks about animals: "[T]he question is not, Can they reason? Nor, Can they talk? but, Can 
they suffer? (Bentham 1789, 310-11, n. 1). ${ }^{15}$ Moreover, scientific developments created an intellectual environment receptive to an anthropomorphized conception of animals. Anthropomorphized depictions of animals became widespread in popular culture and scientific literature, generating a receptiveness to new ideas about the standards of treatment animals deserved (E.S. Turner 1964, 51-64; Ritvo 1987, 31-32, 298, n. 114).

The central legal antecedents of the animal cruelty movement were the aggressive enforcement mechanisms achieved by the temperance movement. In the 1830s and 1840s, the temperance movement emerged as the first movement to explicitly advocate against family violence (Pleck 1987, 49-66; Siegel 1996, 2127). In the 1850s, state legislatures enacted laws expanding the role of the police in arresting individuals for intoxication, and held inns, restaurants, and liquor stores liable for serving alcohol to intoxicated people or to people who had been identified as habitual drunks. Wesley MacNeil Oliver's research reveals that "[t]he modern notion of probable cause, as an evidentiary threshold permitting a search or arrest that can be satisfied by the fruits of an officer's investigation, is a creation of the mid-nineteenth century" temperance movement (Oliver 2010, 377). The first prohibition statute, enacted in Maine in 1851, and amended and adopted in 1853, was innovative in allowing liquor searches after "three complainants swore that they had probable cause to believe alcohol would be discovered in the search" (Oliver 2010, 409). According to Oliver, from the generic standard of allowing evidence of suspicion to be presented to the magistrate at a later time, "it would be no great leap to permit officers to perform arrests when the facts available to them provided probable cause to believe a crime had occurred and the suspect had committed it" (Oliver 2010, 409).

Even more dramatically, the 1857 New York temperance law, which a judge later invoked as a precedent to defend the arrest powers of the ASPCA, required police to immediately arrest all intoxicated people in public places, with no requirement of a warrant (Davis v. American Society for the Prevention of Cruelty to Animals, 16 Abb. Pr. (N.S.) 73 (1878)). The statute made it the "duty of every such officer, whenever he shall find any person intoxicated in any public place, to apprehend such person and take him before some magistrate of the same city or town" and, if the person was too intoxicated to take an oath, the person was to be put in jail until he became sober, at which point the person was to be fined ten dollars and potentially keep in jail

15. Peter Singer's Animal Liberation, which began the contemporary animal rights movement in the mid-1960s, for example, extends and politicizes Bentham's analysis, but adheres unwaveringly to his strict utilitarian approach.

Early animal welfare advocates made similar arguments to demonstrate the immorality of inflicting harm on animals at least thirteen years before Bentham's Principles of Morals and Legislation. An example of the developing animal welfare sentiment can be seen in the writings of Humphry Primatt, who argued in his The Duty of Humanity to Inferior Creatures (1776) that:

Pain is pain, whether it be inflicted on man, or on beast; and the creature that suffers it, whether man or on beast; ... being sensible of the misery of it, whilst it lasts, suffers evil; and the sufferance of evil, unmeritedly, unprovokedly, where no offence has been given, and no good end can possibly be answered by it, but merely to exhibit power or gratify malice, is cruelty and injustice in him that occasions it. A brute ... has similar nerves and organs of sensation; and his cries and groans, in case of violent impressions upon his body, though he cannot utter his complaints by speech or by human voice, are as strong indications to us of his sensibility to pain, as the cries and groans of a human being, whose language we do not understand (as quoted in Brown 1988, 30-31). 
or a work house for ten days. ${ }^{16}$ By requiring police to immediately arrest intoxicated persons and by establishing a streamlined criminal process to prosecute offenders, the temperance laws led to a rapid and massive impact (Bordin 1981; Epstein 1981; Montgomery 1993, 64-71; McGirr 2016). As will be described, the post-Civil War animal cruelty laws vested the power to arrest in private ASPCA officials. Judges upheld ASPCA arrests even when the common law requirements of breach of the peace or common law privacy might have dictated otherwise.

From the start, the animal welfare movement had two dimensions. One aspect of reform was propelled by concern for animal suffering. The second and more compelling reason for the emergence of animal cruelty laws involved a widespread desire for greater social control measures. The quintessential animal cruelty prosecutions in the late nineteenth century involved men who drove horses pulling carts or buses for a living, or the suppression of entertainment like cock-fighting and bull-baiting, which were perceived as disorderly events of the lower class. Like the temperance movement, the animal cruelty movement lobbied for favorable legislation to use the power of policing and enforcement to achieve social transformation rapidly.

\section{THE EARLY ASPCA: ENFORCING ANTICRUELTY IN NEW YORK}

In 1865, Henry Bergh obtained the signed endorsement of one hundred prominent people in New York City in support of his Declaration of the Rights of Animals and thereby began the American animal welfare movement (Steele 1942, 36; Pearson 2011). In 1866, Bergh successfully fought in the New York state legislature for the ASPCA's first charter. Importantly, the Charter itself required the police force to support the ASPCA in enforcing the animal cruelty laws: it stated that "[t]he police force of the city of New York ... shall, as occasion may require, aid the society ... in the enforcement of all laws ... enacted for the protection of dumb animals." 17 Bergh achieved a number of other legislative successes in 1866, and he campaigned for more expansive anticruelty legislation. ${ }^{18}$ On April 12, 1867, New York's legislature enacted a landmark statute which broadened the forms of animal cruelty constituting a

16. Laws of New York 1857, Vol. 2, ch. 405, \$17. See John 2015, 141-67.

17. Laws of 1866, ch. 469, $\$ 7$ ("AN ACT TO incorporate the American Society for the Prevention of Cruelty to Animals." Passed April 10, 1866), cited in ASPCA, First Annual Report 1867, vii. On fines accruing to the Society, see ibid., at vii $(\$ 8)$.

18. On April 13, 1866, the legislature enacted a statute limiting railroad companies from confining animals in train cars for longer than twenty-eight hours: "AN ACT For the Preservation of the Health of Animals for Human food, passed April 13, 1866." Laws of New York vol 2, ch. 560, at 1210, (§ 1), cited in ASPCA, First Annual Report (1867), at 60-61. On April 19, 1866, the legislature passed a more general act, which largely repeated the language of the Act of 1828, prohibiting "maliciously kill[ing], maim[ing], wound[ing], injur[ing], tortur[ing] or cruelly beat[ing] any horse, mule, ox, cattle, sheep, or other animal belonging to himself or another." The law also prohibited leaving animals to die in the street, stating that:

[Section 2] Every owner, driver or possessor of an old, maimed, or diseased horse or mule, turned loose or left disabled in any street, lane or place of any City of this State, who shall allow such horse or mule to lie in any street, lane or public place for more than three hours after knowledge of such disability, shall, on conviction, be adjudged guilty of a misdemeanor. ("AN ACT Better to Prevent Cruelty to Animals. - Passed April 19, 1866." 1866 Laws of New York, Vol. 2, ch. 682, at 120, (§§1-2), cited in ASPCA, First Annual Report 1867, 61-62. 
crime. Over-driving, overloading, torturing, depriving of sustenance, or beating any living creature; being "any way ... connected with" or receiving money as admission for "fighting or baiting any bull, bear, dog, cock, or other creature"; carrying an animal in a vehicle in an "inhuman" manner; abandoning a sick or disabled creature; and using dogs to drive carts without the proper license were all violations of the statute (ASPCA, First Annual Report 1867, 62-65). Moreover, the law authorized any agent of the ASPCA designated by the sheriff to immediately arrest without a warrant individuals in violation of the statute. ${ }^{19}$ One half of all fines collected under the Act would be donated to the ASPCA. In sum, the legislature gave ASPCA members the authority and the incentive to aggressively enforce the new statute.

The movement aimed not for animal rights but, as the first ASPCA Secretary's Report stated, to achieve "an observance of tenderness and humanity towards the inferior dependents of mankind," and to civilize the animals' oppressors (ASPCA, First Annual Report 1867, 3). The ASPCA explicitly stated that its founding purpose was to work with the police to secure prosecutions under the new anticruelty laws (ASPCA, First Annual Report 1867, vii). The Society's focus on prosecutions is revealed in the First Annual Report's section entitled "Suggestions for the Guidance of Persons desirous of Prosecuting Individuals Guilty of Cruelty to Animals," which provided a detailed guide on executing citizens' arrests, and instructions for Police Captains on implementing the law. The ASPCA instructions describe how to achieve an arrest by: (1) Giving the offender into the custody of a police officer; (2) Issuing a Summons; or (3) Apprehending the accused under a warrant (ASPCA, First Annual Report 1867, 66-68).

The ASPCA immediately focused its efforts on arresting individuals for animal cruelty. Typical prosecutions during the early years of the ASPCA involved working class men who used animals in the course of their employment. Many of the first violations were also unquestionably "public" in that they occurred on the streets of New York. As an example, the first ASPCA arrest, reported in the New York Times, was as follows:

The offender is a German butcher named MANZ, living in Brooklyn, and the offence carrying a load of calves in his cart, piled up like wood, their legs tightly bound up by cords, and one of them so disposed of as to bring his eye in contact with a sharp stick, thereby destroying the sight, and threatening, at each motion of the vehicle, to tear it out of the socket (New York Times 1866, 8).

ASPCA officials also frequently targeted men who used horses to drive stage cars full of passengers or to pull carts. Henry Bergh himself wandered the streets of Manhattan for several years on a constant lookout for tired or injured horses (McCrea 1910, 151-52).

Each Annual Report thereafter included glorified accounts of the Society's arrests and detailed reports of every conviction. The Second Annual Report expresses the

19. Under the statute, "Any agent of the American Society for the Prevention of Cruelty to Animals, upon being designated thereto by the sheriff of any county in this State, may, within such county, make arrests and bring before any court or magistrate thereof, having jurisdiction, offenders found violating the provisions of this act." Laws of 1867 , ch. $375, \S 8$. 
Society's "deep gratitude" to the Metropolitan Police Force, and to the judiciary (ASPCA, Second Annual Report 1868, 9). Indeed, the Report notes that the ASPCA's Charter required the police to "aid the Society" and that: "No higher encomium could be passed on this admirably administered engine of order and security in society, than to say that the foregoing injunction has been promptly and faithfully carried out" (ASPCA, Second Annual Report 1868, 9). Other states soon followed New York's model, adopting similar statutes and giving ASPCA members authority to arrest without warrants (McCrea 1910, 14-15).

One of the first prominent reported court cases was People v. Tinsdale, an 1868 case involving an overloaded passenger train car for the Bleeker Street and Fulton Ferry Railroad (10 Abb.Pr.(N.S.) 374, 374 (1868)). The case was brought by a police officer working together with ASPCA founder, Henry Bergh. The officer testified that the "car was unusually crowded, ... one of the horses slipped twice, and ... some of the passengers were compelled to aid the horses in putting the car in motion" (ibid., 377). Bergh testified as well. The defendants, the driver and conductor of the car, argued that they were exempt from liability because they were merely agents of the railroad company who did not select the horses they drove. In instructing the jury, the court rejected the argument that the proper defendant was the owner of the company and held that the impact on the animals, rather than the driver's intent, was the decisive issue in the case. The court emphasized that "[t]he commission of the offense under the statute does not rest upon the question of intent. The intent is assumed from the act itself" (ibid., 374). The court upheld the convictions of the driver and conductor and the two men were each fined $\$ 250.00$ (ibid., 379). People v. Tinsdale was important for the ASPCA because the judge formally recognized that the 1867 New York law repudiated common law intent requirements. The judge made no mention of the requirement of a breach of the peace or public harm. The case legally recognized that the ASPCA statutory arrest powers authorized them to immediately arrest individuals committing animal cruelty, including workers such as drivers of passenger trains and stage cars drivers (like the immediate arrest of an intoxicated person).

The scope of the ASPCA's arrest powers was challenged in court again five years later in The Stage Horse Cases (15 Abb.Pr.(N.S. 51 (1873)). In the case, several stage horse companies banded together to prevent Henry Bergh from harassing their employees during the workday (ibid.). The companies sued for an injunction to bring an end to the ASPCA officials' routine practice of stopping stage cars to examine the horses for injury or disability, arresting drivers, and impounding horses found to be unfit to drive (ibid., 51). The legal issue in the case was whether, in making these stops, the ASPCA officials exceeded the arrest powers granted in the 1867 statute by interfering with the legitimate operations of corporate franchises in New York, when there was no claim of a breach of the peace.

In another ASPCA legal victory, the judges resolved the case in its favor, denying the request for a broad injunction against the ASPCA. Judge Daly noted that under the common law, warrantless arrests were only authorized in the case of felony offenses. However, the New York animal cruelty laws of 1867 clearly authorized ASPCA officials designated by the sheriff to arrest without a warrant for the misdemeanor offense of animal cruelty in the absence of a breach of the peace. According to Judge Daly, he was: 
inclined to agree ... that the act of 1867 was passed to remedy a supposed defect in the common law-i.e., that an arrest without warrant could not be made in the case of a misdemeanor committed in the presence of the officer unless it tended to a breach of the peace (ibid., 62 (emphasis added)).

He noted that "the agents of that society have power to arrest, without warrant, offenders against the provisions of the act where the offense is committed in the presence of the person making the arrest. I can make no order restraining the arrests generally; because a proper cause for making them may arise" (ibid., 65). Similarly, Judge Shea's opinion suggests that he was principally concerned with strengthening the authority of law enforcement officials. According to Shea, "Public policy demands that a public agent of the law shall be presumed, until the contrary clearly and strongly appears by competent proof, to have been acting within a power which for public purposes has been conferred upon him" (ibid., 75). Nonetheless, the judges enjoined the ASPCA officials from seizing the affected horses, because the 1867 act did not authorize them to "take charge of the horses," or to "send them to the stables," or to "interfere between the driver and his passengers, or to require any fares to be paid back." According to the court, the power of the ASPCA officials was "wholly confined to the making of arrests" (ibid., 66). The Stage Horse Cases, however, is remarkable for confirming that a breach of the peace was not required for an arrest and conviction under the 1867 Act.

There were 101 convictions in New York in 1866-1867; 222 convictions in 1867$1868 ; 264$ in 1868-1869; 269 in 1869-1870; 312 in 1870-1871; and 365 in 1871-1872 (ASPCA, Sixth Annual Report 1872, 14; see also McShane and Tarr 2007, 48-49; Pearson and Smith 2014, 131-32). In the statute's first year (1866-67), almost half of the New York convictions (41 out of 101) were for "cruelly beating Horses or other Animals with whips, clubs or other weapons" (ASPCA, Sixth Annual Report 1872, 14). In the same year, ten people were convicted for "carrying Animals in a cruel or inhuman manner," fifteen for driving lame and disabled horses, three for overloading horses, twenty for "Acts of cruelty to Cattle, Dogs, Cats, Poultry, \&c" and twelve for starving or abandoning animals. The trend shifted over the first six years. In the first six years, the most frequent crime was "driving lame, sick or disabled Horses," it accounts for 819 of 1533 convictions. Descriptions of individual convictions reveal that this crime typically involved driving a horse with sores on its body (ASPCA, Sixth Annual Report 1872, 14). Dog- and cock-fighting were frequently attacked in the ASPCA literature, but account for only 31 convictions in the six year period 1866-1872 (although general "acts of cruelty" that could include such games account for 126 convictions in the period 1866-1872) (ASPCA, Sixth Annual Report 1872, 14). Each conviction typically imposed a fine of $\$ 5.00$ to $\$ 15.00$ (up to $\$ 300$ if the accused behaved defiantly) and could include a prison stay of ten days (though at times, up to a month).

As the historian Linda Gordon has emphasized, it is impossible to ignore the inherent class-bias of the ASPCA in its earliest years (Ritvo 1987, 137-42; Gordon 1988, 34). In the nineteenth century, like now, both rich and poor engaged in activities that inflicted pain on animals or caused the death of animals. Not only were Americans largely carnivorous, but sport-shooting birds, fox hunting, and hunting other animals were extremely popular among the wealthy. Vivisection was still respected as a scientific practice. And, of course, people relied constantly on the use of horses, mules, and other 
animals for their labor. The records of the period 1866 to 1872 list no convictions for any activity that could be interpreted as an "upper class" activity. The ASPCA had denounced vivisection from the outset (ASPCA, First Annual Report 1867, 19-22). Indeed, Henry Bergh attempted to include an anti-vivisection provision in New York's 1867 animal welfare act, and introduced a bill making vivisection a misdemeanor into the New York legislature-the first of its kind in the country-in 1880. His efforts failed at every stage (Lederer 1987, 237-38). In practice, arrests were almost exclusively of members of the working class.

In addition, the New York ASPCA Reports prior to 1872 describe no convictions for hunting, despite Henry Bergh's overtures against the practice. On January 1, 1867, several men were arrested for "shooting chickens on New Year's Day for sport, and thus mangling the fowl till it could not stand" (ASPCA, First Annual Report 1867, 50-51). Justice Connolly dismissed the case, claiming that it was "an old sport of the boys, and he would not interfere with it!" (ASPCA, First Annual Report 1867, 51). Fox hunting was a sport with specific rules and etiquette that was likely to be comprehensible to the wealthy. In contrast, cock-fighting and bear-baiting were perceived as more barbaric, drawing crowds of unruly men who unleashed their "vicious" emotions while gambling on the animals' deaths. ${ }^{20}$

Unlike many animal rights activists today, animal welfare advocates of the nineteenth century never conceived of emancipating animals from human domination (Regan 1983; Singer 1990). Thus, the goals of the movement were not to eliminate animals' dependency on human beings. The animal welfare movement's founders popularized the image of animals as anthropomorphized victims by frequently using the language and imagery of slavery, depicting animals as slaves, in an idealized and romanticized form, to provide poignant examples to strengthen their arguments (ASPCA, Third Annual Report 1869, 5). Henry Bergh's principal anticruelty advocacy speech-entitled Our Speechless Slaves — emphasized that his call to animal welfare advocacy was motivated by his "[f]eeling that this was a great neglect and injustice to these creatures which serve us so faithfully and devotedly" (Bergh, Cincinnati Daily Gazette 1873). ${ }^{21}$ Whereas antislavery

20. Those who believed themselves of a higher status than, say horsedrivers or cock-fighters, viewed themselves as having the "right" to intervene and regulate these people's control over their property. Lord Erskine's speech to the British Parliament, the first advocacy effort for animal protection laws in Britain, exemplifies this sentiment. According to Erskine, when told not to beat an animal, "If the offender be a servant, he curses you, and asks, 'if you are his master?'” Lord Erskine expressed his offense that an inferior held a property right permitting him to exercise his dominion over another living being and to reject the moral demand of a superior (Erskine 1809, 554).

21. There is some evidence of direct ties between abolitionists and animal welfare advocates. George T. Angell, for example, who in 1868 founded the Massachusetts Society for the Prevention of Cruelty to Animals (Mass. SPCA), the second most prominent and active of the animal advocacy societies, shared a law office for twenty years with Samuel E. Sewall, a prominent abolitionist (Angell 1892, 10-11). A critic of the movement (and of abolitionism) stated that "[Animal welfare advocates] belong to the same party whose humanitarian tenderness stirred up a Civil War which carried desolation to millions of human habitations" (Sunday Mercury 1866, quoted in Steele 1942, 45).

There is substantial evidence that many abolitionists believed in protecting animals from cruelty. Abraham Lincoln, for example, had a lifelong interest in preventing cruelty to animals (Wilson 1998, 305). According to Sydney Coleman, a historian of the humane movement,

It was more than mere coincidence that the humane movement in England and America followed so closely upon the abolition of human slavery. ... [With the Civil War,] the rights of the defenseless were established. The conscience of a nation was stirred to its depths, and 
activists had characterized the evils of slavery as relating to the dangers of power and domination, rather than focusing on the inherent inequities of slavery as an employment relationship, animal welfare activists tried to gain popularity by characterizing animals as "employees" (Davis 1992, 161-79). Thus violence toward animals was deplorable because animals gave loyalty and labor for free (ASPCA, Third Annual Report 1869, 6-7). It was through this medium that the animal welfare movement drew from antislavery ideology: The moral foundation of the movement was based on the conception that animals were hard-working "slaves" needing legislative protection.

The descriptions of individual convictions reveal that the people most frequently arrested were those who used horses to transport goods (such as bricks, dirt, feed, coal, wood, or other goods) throughout the city. ${ }^{22}$ It is clear from the ASPCA Annual Reports that the members of the Society largely viewed themselves as suppressing barbaric and brutish behavior. Violently whipping a horse until it bled, cock-fighting, torturing animals, were viewed both as indefensible treatment of animals, and socially subversive and emblematic of the threat of the dangerous class. In reality, however, the convictions can be divided into two groups: gratuitous violence against animals, and economically driven harm to animals. Gratuitous violence includes torture, such as David Heath's arrest on March 30, 1866 for "taking a cat by the hind legs, and placing it on a truck, and with his crutch beating out its brains" (ASPCA, First Annual Report 1867, 55). The second group of crimes, however, was not so clearly gratuitous or founded in bad intentions. As mentioned above, 819 of the 1533 crimes in the first five years of the ASPCA in New York were for driving an injured horse. The ASPCA met with resistance at times. The ASPCA reported that on September 3, 1869, for example, the police officer Samuel Morrison was convicted for "inciting a mob of seventy-five to one hundred persons, by speech and manner, to resist the enforcement of the law, in the case of three trucks overloaded with hay, and refusing to make an arrest when requested by Mr. Bergh" (ASPCA, Fourth Annual Report 1870, 50)23 But ASPCA efforts were supported by the press. To give one of many examples, in 1866, the New York Times published an article, notably, entitled "The Rights of Animals," which emphasized that "the

resulted in the development of an era of humanitarian progress heretofore unknown. Under such conditions it was most natural that the unfortunate lot of animals should attract attention (Coleman 1924, 33).

In Britain, the ties between abolitionism and protecting animals from cruelty were more explicit. Indeed, two of the principal supporters of Britain's first anticruelty statute were William Wilberforce-widely credited with Britain's abolition of the slave trade-and Sir Samuel Romilly, a prison reformer and abolitionist (Fairholme 1924, 18, 21-22). Fairholme claimed that Wilberforce's "love of animals was as ardent as his sympathy for human slaves" (ibid., 18).

22. See ASPCA, First Annual Report 1867 (Prosecutions and Convictions), 47-57; Second Annual Report (1868) (Arrests and Convictions), 57-73; Third Annual Report (1869) (Arrests and Convictions), 47-67; Fourth Annual Report (1870) (Arrests and Convictions), 45-70; Fifth Annual Report (1871) (Convctions), 23; Sixth Annual Report (1872) (Cases Prosecuted), 14; Seventh Annual Report (1873) (Cases in Abeyance), 20; Eighth Annual Report (1874) (Record of Cases Prosecuted), 11; Ninth Annual Report (1875) (Record of Cases Prosecuted), 20; Tenth Annual Report (1876) (Record of Cases Prosecuted), 18.

23. On November 29, 1869 a man was convicted of "whipping his horses, being remonstrated with by [sic] Mr. Bergh for his conduct, and becoming very abusive." He was fined $\$ 10.00$ and bound in $\$ 300$ to keep the peace. ASPCA, Fourth Annual Report 1870, 56. 
extent and diabolical character of the cruelty that consists in running omnibus and car horses until they drop down and then leaving them to die in the streets, are shocking" (New York Times 1866). ${ }^{24}$

State legislatures around the country enacted animal cruelty laws similar to New York's 1867 law in the decades after the Civil War. The legal cases brought under the acts illustrate the efforts of animal cruelty reformers to expose the reach of the statutes and to push cruelty enforcement into areas that would have been unheard of under the old common law doctrines. The judicial decisions reveal that courts interpreted the statutes as creating an entirely novel type of offense, rooted in the suffering of the animals. The next part describes the doctrinal issues relating to animal cruelty that courts addressed in the post-Civil War Era.

\section{THE MORAL TURN IN THE COURTS: THE HARM OF CRUELTY}

The aggressive efforts by animal welfare reformers to bring prosecutions under the post-Civil War statutes compelled judges to address whether to interpret the statutes conservatively, as codifying earlier common law prohibitions on cruelty amounting to public harms or malicious mischief or, in contrast, whether to interpret the statutes as introducing a new criminal offense rooted in the suffering of animals.

\section{A Crime Rooted in Animal Suffering}

A striking example of a case that treated the 1867 law as creating new offenses was People v. Brunell, an 1874 New York case brought by the ASPCA against drivers of horse-drawn passenger carts, described at the outset. It exemplified a shift in judicial reasoning to a focus on animal suffering, rather than on the harm to the public incident to witnessing cruelty (48 How.Pr. 435, 435 (1874)). Judge Sutherland's jury instructions framed the harm as the cruelty, not the harm to the public. He emphasized:

Pain is an evil. Why should dumb creatures, domesticated to obey us, confiding in us, indebted to us for their food and subsistence, bound and taught to obey us, be unnecessarily and unjustifiably inflicted with pain? ... I think all agree that Mr. Bergh's efforts, and the efforts of the officers of his society, in a discreet and judicious manner to enforce these laws for the protection of animals, and to prevent cruelty to them, deserve all praise (ibid., 437).

Demonstrating a shift to concern for the animals, from the perspective of the animals themselves, he told the jury:

24. On June 24, 1865, the New York Times published an article titled "Cruelty To Animals-An Outrage Demanding Attention," which oriented readers around the animals' perspective with remarks such as:

If they were killed and plucked, the publicity of the thing might be endured; but I have repeatedly seen these poor creatures in the hands of the torturers, having been dipped into hot water, and now, without a feather remaining, still able to utter their plaintive cry of agony! (New York Times $1865,8)$. 
the thousands of omnibus horses in this city, ... are now pleading with you not to convict these prisoners against evidence or law, but to do this-to carefully examine the evidence, and honestly and carefully render a verdict according to the law and the evidence, free from any prejudice or feeling (ibid., 446 (emphasis added)).

Judge Sutherland's advice to the jury reveals the mechanism by which the sympathetic conception of animals advanced by animal welfare advocates was dispersed to the public and translated into a greater volume of convictions. By emphasizing the animals' status as in a dependency relationship with humans, and by promoting an anthropomorphized conception of animals — describing the horses as "pleading" with the jury-he pushed the jury toward adopting the animal welfare agenda as defined by the ASPCA and other groups. It is, perhaps, no surprise that the jury returned a verdict of guilty against the two defendants in the case (who were then fined $\$ 200$ and $\$ 250$, respectively). More important, People v. Brunell exemplifies the way in which receptiveness to the animal welfare crusade led judges to articulate the crime of animal cruelty in terms of the inherent wrongfulness of the suffering of innocent, dependent, sentient beings.

Grise v. State, decided by the Supreme Court of Arkansas in 1881, in dicta more explicitly interpreted the animal cruelty law as creating a new type of offense (37 Ark. 456, 457 (1881)). Grise involved a man who killed a neighbor's pig that had routinely entered Grise's property and eaten his crops. Grise killed the pig by hitting it once, according to the court, "with no more circumstances of cruelty than would attend the taking of life at one blow" (ibid., 457). Grise was prosecuted under a provision of an 1879 Arkansas anticruelty act, which made it a misdemeanor to "needlessly mutilate or kill ... any living creature." As in many cases where animals were killed for repeated trespassing, the Supreme Court of Arkansas held that Grise had not "needlessly" killed the animal. ${ }^{25}$

The significance of Grise is that it was the first case in which the Arkansas Supreme Court interpreted Arkansas's anticruelty statute, which was enacted in 1879 and modeled on New York's statute. The court interpreted the statute in very radical terms, emphasizing that it intended "to transcend what had been thought, at common law, the practical limits of municipal government" (ibid., 458). According to the court, modern animal anticruelty statutes:

are not made for the protection of the absolute or relative rights of persons, or the rights of men to the acquisition and enjoyment of property, or the peace of society. They seem to recognize and attempt to protect some abstract rights in all that animate creation, made subject to man by the creation, from the largest and noblest to the smallest and most insignificant. ... The peculiar legislation we are now called to discuss must be considered wholly irrespective of

25. The court found that Grise had taken extensive measures to prevent having to kill the pig. He built a good fence, although the pig became able to slip under it. He pleaded with the pig's owner to pen it in. Moreover, after killing the pig, Grise immediately paid the owner the value of the pig. Grise was like other cases in which courts routinely decided that people who killed trespassing animals lacked the necessary malice to be indicted under malicious mischief doctrine. See Wright v. Georgia, 30 Ga. 325 (1860); Duncan v. State, 49 Miss. 331 (1873); Fairfax Branch v. State, 41 Tex. 622 (1874); Darnell v. State, 6 Tex. App. 482 (1879); Thomas v. State, 14 Tex. App. 200 (1883) (defending sheep); Hodge v. State, 79 Tenn. 528 (1883) (defending hen house from neighbor's dog); State v. Butts, 92 N.C. 784 (1885). 
property, or of the public peace, or of the inconveniences of nuisances. The misdemeanors attempted to be defined may be as well perpetrated upon a man's own property as another's, or upon creatures, the property of no one, and so far as one act is concerned, it is all the same whether the acts be done amongst refined men and women, whose sensibilities would be shocked, or in the solitude of closed rooms or secluded forests (ibid., 459 (emphasis added)).

Grise was radical in explicitly articulating the view that the animal anticruelty statutes "seem to recognize and attempt to protect some abstract rights" in animals. Moreover, the case interpreted the Arkansas statute extremely broadly as applying to cruelty even occurring "in the solitude of closed rooms or secluded forests." Grise's holding was limited to a finding that Grise was justified in killing the hog in question. The dicta cited above, however, invited the police and animal welfare advocates to bring actions against people who subjected animals to suffering, no matter where or in what context the cruelty occurred.

\section{The Question of Common Law Privacy and the Requirement of a Breach of the Peace}

In the courts of New York, the judges were not in consensus on the proper interpretation of the animal cruelty laws. Whether, substantively, the law vastly changed the nature of the offense of animal cruelty was in dispute. All agreed, however, that the power of warrantless arrests conferred upon ASPCA officials was a departure from earlier precedents. In The Stage Horse Cases, where the principal issue was the extent of ASPCA officials' arrest power, the judges treated the law more conservatively. Judge Daly stated his view that the 1867 act "was declaratory only of the common law." Yet, he noted that at common law "deliberation was necessary, as evidencing the wicked intent to inflict injury upon the animal," for a conviction for animal cruelty (Broadway et. al. v. American Society for the Prevention of Cruelty to Animals, Christie v. Bergh, 15 Abb.Pr.(N.S.) 51, 63 (1873)). ${ }^{26}$ In contrast, "Under this act of 1867, certain of the offenses designated are by their commission alone evidence of a willful intent to commit a misdemeanor-such as overloading or overdriving, ... cruelly beating or needlessly mutilating or killing or depriving of necessary sustenance, any dumb animal."(ibid., 63-64). Thus Judge Daly emphasized continuity with the common law, while recognizing that the statute eliminated the "malice" requirement of the animal cruelty offense. Moreover, finding that the conduct constituted a breach of the peace was no longer required. Therefore, in this case, the ASPCA officials were justified in stopping the cars when the horses were treated cruelly.

In contrast, Judge Shea argued that the 1867 statute allowed only prosecutions for cruelty amounting to public nuisances. According to Shea:

26. Citing People v. Ross, 3 City Hall Rec. 191, "where a carman, intending to beat his horse for refusing to draw its load, struck it a single blow upon the neck, which killed it. He was acquitted on the ground that the evidence showed no deliberate intention to kill the animal, but only to chastise it." 
It is not correct to assert that the policy of this kind of legislation, especially that which has for its purpose the prevention of cruelty to brutes, is a regulation of the dominion of the private citizen over his own private property merely. It truly has its origin in the intent to save a just standard of humane feeling from being debased by pernicious effects of bad example-the human heart from being hardened by public and frequent exhibitions of cruelty to dumb creatures, committed to the care and which were created for the beneficial use of man. ...

[Cruelty to animals constitutes] "a breach and violation of the public rights and duties, owing to the whole community, considered as a community, in its social aggregate capacity," and though "of consequence, private vices or the breach of mere absolute duties, which man is bound to perform considered only as an individual, are not, cannot be, the object of any municipal law;" yet when by 'their evil example or other pernicious effects they may prejudice the community and thereby become a species of public crimes. Thus the vice of drunkenness, if committed privately, is beyond the knowledge, and, of course, beyond the reach of human tribunals; but if committed publicly, in the face of the world, its evil example makes it liable to temporal censures" (ibid., 77, 78).

Driving injured or disabled horses did not amount to a breach of the peace. Yet, as described above, Judge Shea rejected the motion for a general injunction because under the statute ASPCA officials were authorized to make arrests. If the stage car companies wanted to make a specific allegation of malicious prosecution against Bergh or others, they would have to do so in another case. The Stage Horse Cases did not reject the requirement of a breach of the peace, but expanded what it encompassed to driving injured or disabled horses when it constituted cruelty.

Similarly, a case in New York, in 1874, was a landmark for further transforming breach of the peace doctrine to include conduct on private property. Davis v. Society for Prevention of Cruelty, was brought by a slaughterhouse company on West $39^{\text {th }}$ Street, requesting an injunction against Henry Bergh and his associates (16 Abb. Pr. (N.S.) 73, 73 (1874)). ASPCA officials had entered its premises and had threatened to close its operations unless the company complied with their demands. Like The Stage Horse Cases, decided the year before, the question before the court was whether Bergh and other ASPCA officials had exceeded their authority under the 1867 anticruelty statute.

Bergh argued that the slaughterhouse company and its employees constantly violated the 1867 statute, not for killing hogs, but because their methods "needlessly tortured and tormented" the hogs before their death (ibid., 75). The slaughterhouse policy was to fasten an iron chain around the hogs' ankles, lift them four stories above their pen, dislocating their legs, then stab them in the throat and immediately plunge them in boiling water, ensuring that they remained alive when they reached the water (ibid., 73). The ASPCA demanded that the company prevent dislocation of the hogs' legs by using a leather strap, and fully kill the hogs before they entered the boiling water.

The judge decided in favor of the ASPCA, denying the slaughterhouse's request for an injunction. The court invoked the 1857 temperance law in New York as a central precedent for allowing warrantless arrests. According to the court, ASPCA officials, "being thus clothed with proper legal authority ... should not be interfered with or restrained; unless [their official action] be injurious and wrongful in its nature" (ibid., 78). Moreover, 
the judge characterized the principal question in analyzing the ASPCA's demands as "whether or not ... wanton acts of cruelty are allowed and practiced, such as dislocating the limbs of the animals slaughtered and plunging them while yet alive in boiling water" (ibid., 78-79). By holding that the 1867 act covered slaughterhouse practices, Davis v. Society for Prevention of Cruelty reflected the acceptance of a greatly expanded conception of the proper scope of government regulatory authority. Notably, it was decided the same year as the first child cruelty case, which was brought by the ASPCA.

\section{Lowering the Threshold for Cruelty: Widespread Rejection of the Malice Requirement and Protection for Owners}

A thread connecting all of the above cases was that focusing on the suffering of animals led to the elimination of the intent element in animal cruelty offenses. The common law requirement of a "cruel" or "malicious" intent suggested that the harm to animals was a secondary effect of the true public crime-unchecked aggression and a dangerous lack of self-control. Malicious mischief, it may be recalled, required malice toward an animal's owner and was characterized as a public crime because the "act discovers a degree of moral turpitude, dangerous to society" (Kilpatrick v. People, 5 Denio 277 (1848), citing People v. Smith, 5 Cow. 258 (1825)). The post-Civil War animal anticruelty statutes made the former elements of the malicious mischief doctrine irrelevant.

First, in cases brought on the issue of whether anticruelty statutes applied when animals were harmed by their owners, judges held that ownership of the animal did not provide immunity from the new laws. ${ }^{27}$ In Commonwealth v. Lufkin, the Massachusetts court held, "The cruel treatment which the statute contemplates is the same, whether inflicted by the owner of the animal or by another. ... The title to the horse has nothing to do with this offence" (89 Mass. 579, 582-83 (1863)). Similarly, State v. Bruner, an Indiana case, held that the animal cruelty law adopted "a scheme for the protection of animals without regard to their ownership. A man may be guilty of cruelty to his own animal, or to an animal without any known owner, or which has in fact no owner" (12 N.E. 103, 104 (1887)). A West Virginia court, citing the Arkansas Supreme Court in Grise, determined "The ownership of the animal is totally immaterial"(State v. Gould, 26 W. Va. 258, 262 (1885)).

Moreover, when the perpetrator of the cruelty was not the owner, courts no longer required malice toward the owner. Indeed, as in the New York cases, judges began inferring a cruel intention from the kind of harm done to the animal. ${ }^{28}$ In State v. Avery, a New Hampshire case, the court stated that "If the beating was wrongful, because cruel and severe, and was done intentionally, ... the law would regard it as malicious" (44 N.H. 392, 396 (1862)).

27. See, for example, Commonwealth v. Lufkin, 89 Mass. 579 (1863); Commonwealth v. McClellan, 101 Mass. 34 (1869); State v. Brocker, 32 Tex. 611 (1870); Commonwealth v. Whitman, 118 Mass. 458 (1875); Rose v. State, 1 Tex. App. 400 (1876); Grise v. State, 37 Ark. 456 (1881); Commonwealth v. Flannigan, 137 Mass. 560 (1884); State v. Greenlees, 41 Ark. 353 (1883).

28. Because killing and injuring animals was not prohibited by any statute-indeed, animals were killed routinely for food and leather, and it was assumed that beating a horse, for example, as part of the process of breaking in the horse was permitted, some evidence of a "cruel" intent was necessary under the statute. 
Whether one could be convicted for conduct driven by a seemingly innocent motivation was prominently addressed in an 1886 Missouri Court of Appeals case, State v. Hackfath (20 Mo.App. 614, 614 (1886)). Hackfath was engaged in hauling lumber with a team of two horses. One of the horses "became balky" and Hackfath tried to make it go "by urging it, and pulling it." As a last resort (he claimed), he struck the horse on the head with a club. The horse then immediately fell down and died. Hackfath asked the lower court to instruct the jury that he should be acquitted unless they found that he had "an intent to torture and kill the horse." Yet, the appellate judge held that at issue were "the consequences of his voluntary act." Because there is "no pretense that the striking of the horse was accidental and not intentional," the lower court conviction should stand (ibid., 614-15). ${ }^{29}$ Similarly People v. Brunell, described above, included the following jury instructions: "The question really is not, gentlemen, whether they intended to torture the horse; the question really is, whether they willfully caused certain things or acts to be done which did necessarily torture the horse" (48 How.Pl. 435, 443 (1874)). In State v. Neal, the Supreme Court of North Carolina upheld a conviction for cruelty in killing a neighbor's chickens emphasizing "This is not a case of 'intent,' which is an inference of inner motive to be drawn by the jury ... but of conduct, cruelty, independent of other intent if willful, and the defendant's own evidence proved that the killing was done willfully" (120 N.C. 613, 621 (1897)). ${ }^{30}$ The Alabama Supreme Court came to a similar conclusion that "Of this offense, malice is not an element. It is against intentional acts, wanton or unlawful, from which injury to the animal results, though the injury may not have been contemplated or intended" (Tatum v. State, 66 Ala. 465, 467 (1880)).

Several cases of the 1870 s and 1880 s suggest that, once the malice requirement was removed, the threshold level of cruelty to sustain a conviction substantially lowered. Again, State v. Hackfath was a conviction for hitting a horse which refused to pull logs, leading inadvertently to its death. A jury convicted a man in Hawaii for riding his horse "while his back and sides were sore, and by leading another horse while in a similar condition" (King v. Tai Wa, 5 Haw. 596, 597 (1886)). A man was convicted in Connecticut for neglecting to provide horses with adequate food, drink, and protection (State v. Bosworth, 4 A. 248 (1886)). Similarly, in Massachusetts "leaving a horse harnessed to a carriage in the woods, where it remains all night uncared for, when it appears the horse was actually without food and drink for more than twenty-four hours" led to a conviction (Commonwealth v. Curry, 150 Mass. 509, 511 (1890)). ${ }^{31}$

\section{Defining "Any Living Creature”}

Yet, on certain issues, the statutory language left room for pushback in the courts. One principal ambiguity was that animals were, in fact, covered under the statutes.

29. Followed by State v. Roche, 37 Mo.App. 480 (1889). See also Commonwealth v. McClellan, 101 Mass. 34 (1869) (minimizing the importance of intent).

30. See also State v. Allison, 90 N.C. 733, 735 (1884) (requiring that cruel acts be done "unlawfully and wilfully, though not maliciously").

31. A man in Massachusetts was convicted for allowing his dog to bite and mangle another dog. See Commonwealth v. Thornton, 113 Mass 457 (1873) (Cf. Commonwealth v. Howes, 26 Pa.D. 610 (1917) (overturning conviction where defendant's dog attacked the plaintiff's dog). 
Remarkably, most of the post-Civil War animal cruelty statutes prohibited inflicting cruelty on "any living creature." As emphasized in Oscar Quinlan's critical 1894 essay on the animal cruelty laws, "'Any living creature' is an astonishingly comprehensive term. It brings the impalement of a worm on a fish-hook, the eating of live oysters, or the boiling of cholera germs within the scope of the letter of the act"(Quinlan 1894, 161). The court in Grise, noted the need to construe the statutes "without running into such absurdities as would, in the end, make them mere dead letters. Society, for instance, could not long tolerate a system of laws, which might drag to the criminal bar, every lady who might impale a butterfly, or every man who might drown a litter of kittens" (37 Ark. 456, 459 (1881)). Perhaps because the ASCPA reformers used discretion in selecting the types of offenses upon which to make arrests, there is an absence of reported cases testing the limits of what "any living creature" meant under the laws. As described above, most animal cruelty prosecutions related to domestic animals, including chickens and other fowl. In an 1887 Indiana case questioning whether the laws applied to burning and tormenting a goose, the court upheld the conviction on the grounds that the statute clearly applied (State v. Bruner, 12 N.E. 103 (1887)).

\section{The Question of Hunting for Sport}

Courts, of course, recognized that "cruelty" depended to some degree on the purpose for which the pain was inflicted or the animal was killed. As the court stated in Commonwealth $v$. Lufkin, "a surgical operation, occasioning the most intense suffering, may be justifiable and is not criminal" (89 Mass. 579, 582 (1863)). In State v. Avery, the New Hampshire court noted that the animal cruelty laws, in parallel with the law regulating parent-child relations, do not "interfere with the infliction of such chastisement as may be necessary for the training or discipline by which such animals are made useful"(44 N.H. 392, 396 (1862)). ${ }^{32}$

Hunting for sport, however, was an area where states came to different conclusions regarding the cruelty of the conduct. In the 1877 case State $v$. Bogardus, the issue before the court was whether shooting pigeons that were thrown up into the air for sport violated Missouri's law which made it an offense to "needlessly ... kill any living creature" (4 Mo. App. 215, 215 (1877), citing Sess. Acts 1874, 112). According to the judge, "The universal love of so-called 'sports' which involve the destruction of animal life cannot now be ignored in a search after the legislative meaning of the act before us." Even when such sports are not related to human sustenance, "they are not considered 'needless' for man's enjoyment of his legitimate dominion over the brute creation" (ibid., 219). Perhaps more remarkable was Commonwealth v. Lewis, a Pennsylvania animal cruelty case of 1891 where the jury convicted a man competing in a pigeon-shooting competition at the local Gun Club. The man missed his target and wounded the pigeon, leading it to fall into a tree (at which point, according to Club rules, another member

32. Ibid., 397 ("If the beating was for the single purpose of breaking the animal of a vicious habit, that was a complete answer to any charge of malice, if he did not go beyond his own rule; but the jury might inquire if the beating was aggravated from the influence of any evil motive, as from violent passion, and at the interference and remonstrance of others, against his severity; for any excess thus caused should be regarded as malicious."). 
finished the job). In reviewing the lower court conviction, the appellate court noted that "the defendant has merely been punished for want of skill" (140 Pa. 261, 266 (1891)). The court noted that although "suffering would be spared wild game if sportsmen were better trained. Skill in shooting upon the wing can only be gained by practice." The court reversed the conviction.

In light of the exemption to the animal cruelty laws carved out in the Missouri and Pennsylvania cases on formal pigeon-shooting, Commonwealth v. Turner, in which the Supreme Court of Massachusetts in 1887 upheld a conviction for fox hunting-where a fox was released, and chased and mangled by dogs — was perhaps surprising, leading to it being a notable precedent (145 Mass. 296, 296 (1887)). Massachusetts state law permitted the killing of foxes and, indeed, authorized towns to give a per head bounty for them. ${ }^{33}$ Therefore, the defendant argued that Massachusetts animal cruelty law was not intended to cover "noxious animals." Moreover, the defendant argued that fox hunting did not violate Massachusetts's anticruelty statute because (like the pigeon-shooting cases) it did not inflict "unnecessary suffering" upon an animal.

The court, however, upheld Turner's conviction for violating the anticruelty law. The court, first, held that the word "animal" was intended to include "wild and noxious" animals, since the word could be found throughout the statute with no limitation. The court then held that "[t]he right to kill a captive fox does not involve the right to inflict unnecessary suffering upon it in the manner of its death" and that letting loose the fox to be mangled by dogs subjected it to "unnecessary suffering"(ibid., 301).

The dicta in Commonwealth $v$. Turner, however, was inconsistent with the line of precedents in that the court invoked an antebellum common law approach. Unlike People v. Brunell and Grise, the court explicitly held that Massachusetts's statute did not define an offense "against the rights of the animals that are in a sense protected." Citing an 1844 Massachusetts case, in which an innkeeper was convicted on public nuisance grounds for hosting a cock-fight, the court in Commonwealth $v$. Turner stated that the "offence is against the public morals, which the commission of cruel and barbarous acts tends to corrupt" (ibid., 300). Invoking public nuisance doctrine flies in the face of the statutory language which, as in other states, appeared to repudiate the older common law doctrines. In one sense, Commonwealth v. Turner represents a substantial expansion of the type of action that qualified as being "against the public morals." Not only was the place in which the fox hunt occurred far more private in nature than the typical animal cruelty offenses had been, but defining a fox hunt as a violation in itself was a radical change in the law. Fox hunts were perceived by the wealthy as a far more civilized sport than, say, cock-fights and bear-baiting events. Fox hunts were perceived as formal and exclusive, and as promoting health and fitness. Commonwealth $v$. Turner is therefore deeply significant to the transformation of animal welfare law because the judge rejected the former class-orientation of the animal welfare movement.

Interestingly, Commonwealth v. Turner served as a precedent in judicial decisions upholding convictions for pigeon-shooting in both North Carolina (1893) and

33. The defendant argued that the common law "warrants the hunting of ravenous beasts of prey, as badgers and foxes, because the destroying of such creatures is said to be profitable to the public" (ibid., 298, citing 3 Bi. Com. 213; Geuslh v. Mynns, Cro. Jac. 321; Gundry v. Felt ham, 1 T. R. 334). 
Colorado (1896). In State v. Porter, the North Carolina Supreme Court emphasized that, "Man's desire for amusement and sport is no justification for the infliction of suffering or death upon any of the creatures protected by the statute .. " (112 N.C. 887, 889 (1893)). The court continued that since the enactment of the statute, "it has been unlawful in this State for man to gratify his angry passions or his love for amusement and sport at the cost of wounds and death to any useful creature over which he has control" (ibid., 889). In Waters v. People, the Colorado Supreme Court heard a case that was brought as a friendly test-case to advise pigeon-shooters on the court's interpretation of Colorado's animal cruelty statute (23 Colo. 33, 33 (1896)). The court recognized the strong differences in private opinion on whether pigeon-shooting constituted unnecessary harm to an animal. The court emphasized, however, that the Massachusetts and North Carolina cases were "in harmony with the advance in enlightened public opinion at this day" and the court viewed these new values as inspiring the Colorado statute (ibid., 39). The Colorado court distinguished the Missouri and Pennsylvania pigeon-shooting cases and emphasized that

Where, as here, the acts charged are admittedly done, not to furnish food, but merely for the sport and amusement of the defendant and his associates, the facts clearly bring the case within the ban of the statute. ... [T]he pain and suffering caused by such acts are disproportionate to the end sought to be attained, and furnish no adequate or reasonable excuse for the acts which to be necessary or justifiable, must be prompted by a worthy motive and a reasonable object (ibid., 39-40). ${ }^{34}$

The opinion grounds the ban on pigeon-hunting on a sense of much-desired social progress in accordance with the times, a social transformation toward more enlightened values.

The convictions for hunting for sport in State v. Porter, Waters v. People, and Commonwealth $v$. Turner reveal the extent to which animal welfare law had transformed. Under these landmark decisions, cruelty occurring on private property, or otherwise removed from direct observation, under the post-Civil War anticruelty laws, was equally offensive to decency and public morals as cruelty occurring on the streets.

\section{CONCLUSION}

Many of the judicial decisions interpreting the post-Civil War animal cruelty laws describe the new statutes as reflective of a new, modern sensibility, recognizing the suffering of animals. In People v. Brunell, referred to at the outset, the judge described the laws as "the result of modern civilization," and based on the principle that "[p]ain is an evil" (48 How.Pr. 435, 437 (1874)). In the 1881 Arkansas case, Grise v. State, the court described the animal cruelty laws as "the outgrowth of modern sentiment," that "seem to recognize and attempt to protect some abstract rights in all that

34. More specifically, the court held that "the killing of captive doves as they are released from a trap, merely to improve one's skill of marksmanship, or for sport and amusement, though there is no specific intention to inflict pain or torture, is, within the meaning of this act, unnecessary and unjustifiable." 
animate creation ... from the largest and noblest to the smallest and most insignificant” (37 Ark. 456, 458 (1881)). State v. Avery described New Hampshire's animal cruelty law as "founded upon a high moral principle, which denounces the wanton and unnecessary infliction of pain, even upon animals created for the use of man, as contrary alike to the principles of Christianity and the spirit of the age" (44 N.H. 392, 396 (1862)).

A powerful apparatus of policing emerged to enforce this modern sensibility of sympathy. The ASPCA relied on immediate arrests as a principal tool. The authority to arrest without a warrant gave the movement a nimble power that could be used on site at the moment cruelty was observed. The ASPCA expanded its reach to conduct, in places, that had not previously been regulated. In cases such as The Stage Horse Cases and Davis v. Society for Prevention of Cruelty, the courts upheld the ASPCA's statutory powers to arrest and viewed arrest power as overriding the common law privacy doctrine and the requirement that the offender commit a breach of the peace. By means of expansive arrest powers, the animal cruelty laws reached animal owners, and conduct on private property, such as inside slaughterhouses.

As described in Joel Prentiss Bishop's treatise of 1873, "Plainly, at this point, the two offences of malicious mischief to animals, and of cruelty to animals, are very wide apart. The former is a crime analogous to larceny, and it is purely a wrong done to the owner of the animal; ... [b]ut the latter is a crime against the animal itself" (Bishop $1873,693, \S 1115)$. Perhaps the most litigated animal cruelty issue was whether "malice" was an element of the animal cruelty offense, and courts widely rejected the requirement. The lack of intent requirement meant that one looked to the animal itself for evidence of violence and suffering.

The post-Civil War animal cruelty legal apparatus centered its efforts in metropolitan areas and on animals providing labor to the urban population. It involved sympathetic legislators enacting statutes with broadly applicable language. It was expanded by ASPCA officials deputized to aggressively bring arrests and provoke lawsuits that pushed judges to expose the reach of the statutory language. In sum, the animal cruelty movement in the post-Civil War era employed political, legal, and judicial measures to impose a new sensibility of preventing animal suffering and punishing cruel conduct, that had radical implications for the areas, such as child welfare, into which it was extended.

\section{REFERENCES}

American Society for the Prevention of Cruelty to Animals (ASPCA). Annual Reports 1865-1875 (Vols. 1-10). New York: The Society, 1867-1941.

Angell, George T. Autobiographical Sketches. American Humane Education Society, 1892.

Beers, Diane. For the Prevention of Cruelty: The History and Legacy of Animal Rights Activism in the United States. Athens: Ohio University Press, 2006.

Bentham, Jeremy. An Introduction to the Principles of Morals and Legislation.1789, reprint of 1823 edition, New York: Hafner Publishing Co., 1948.

Bergh, Henry. "Our Speechless Slaves.” Cincinnati Daily Gazette, 12 December 1873. 
Bishop, Joel Prentiss. New Commentaries on the Criminal Law Upon a New System of Legal Exposition. 8th ed. Chicago: T.H. Flood, 1892.

- Commentaries on the Law of Statutory Crimes. Boston: Little Brown, 1873.

Blackstone, William. Commentaries on the Laws of England (Vols. 1, 4). Facsimile ed. Chicago: University of Chicago Press, 1979 (1765-69).

Bordin, Ruth. Woman and Temperance: The Quest for Power and Liberty, 1873-1900. Philadelphia: Temple University Press, 1981.

Brickey, Kathleen F. "Criminal Mischief: The Federalization of American Criminal Law." Hastings Law Journal 46 (1995): 1135-74.

Brown, Darryl. "History's Challenge to Criminal Law Theory." Criminal Law $\mathcal{E}$ Philosophy 3 (2009): 271-87.

Brown, Les. Cruelty to Animals, The Moral Debt. Hong Kong: Macmillan Press, 1988.

Carson, Gerald. Men, Beasts, and Gods: A History of Cruelty and Kindness to Animals. New York: Scribner, 1972.

Clark, Elizabeth B. "'The Sacred Rights of the Weak': Pain, Sympathy, and the Culture of Individual Rights in Antebellum America." The Journal of American History 82 (1995): 463-93.

Coleman, Sydney H. Humane Society Leaders in America, with a Sketch of the Early History of the Humane Movement in England. Albany, N.Y.: The American Humane Association, 1924.

Cronan, William. Nature's Metropolis: Chicago and the Great West. New York: W.W. Norton, 1991.

"Cruelty to Animals_First Case of Punishment under the New Law." New York Times, 13 April 1866: 8.

"Cruelty to Animals-An Outrage Demanding Attention." New York Times, 24 June 1865: 8.

Davis, David Brion. The Problem of Slavery in Western Culture. Ithaca: Cornell University Press, 1966.

—. "The Problem of Slavery in the Age of Revolution, 1770-1823." In The Antislavery Debate: Capitalism and Abolitionism as a Problem in Historical Interpretation, ed. Thomas Bender. Berkeley: University of California Press, 1992.

Davis, Janet M. The Gospel of Kindness: Animal Welfare and the Making of Modern America. New York: Oxford University Press, 2016.

Epstein, Barbara Leslie. The Politics of Domesticity: Women, Evangelism, and Temperance in NineteenthCentury America. Middletown, CT: Wesleyan University Press, 1981.

Erskine, Lord "Debates in the House of Lords, Parliamentary Debate: Cruelty to Animals, 15 May, 1809." In Parliamentary Debates: From the Year 1803 to the Present Time. Vol. XIV. London: T.C. Hansard, 11 April-21 June 1809.

Fairholme, Edward G. A Century of Work for Animals: The History of the R.S.P.C.A., 1824-1924. London: John Murray, 1924.

Favre, David, and Vivien Tsang. "The Development of Anti-Cruelty Laws During the 1800s." Det. C.L. Review (1993): 1-35.

Foucault, Michel. Discipline $\mathcal{E}$ Punish: The Birth of the Prison. Translated by Alan Sheridan. New York: Vintage Books, 1979.

Francione, Gary L. Animals, Property and the Law. Philadelphia: Temple University Press, 1995.

Glenn, Myra C. Campaigns Against Corporal Punishment: Prisoners, Sailors, Women and Children in Antebellum America. Albany: SUNY Press, 1984.

Goluboff, Risa. Vagrant Nation: Police Power, Constitutional Change, and the Making of the 1960s. New York: Oxford University Press, 2016.

Gordon, Linda. Heroes of Their Own Lives: The Politics and History of Family Violence. New York: Viking Press, 1988.

Grossberg, Michael. Governing the Hearth: Law and Family in Nineteenth Century America. Chapel Hill: University of North Carolina Press, 1985.

John, Juanita. "Wives' Lawsuits Addressing Husband Drunkenness: Tempered by Gender Standards, 1850-1910." Yale Journal of Law EO Feminism 27 (2015): 141-67.

Lansbury, Coral. The Old Brown Dog: Women, Workers, and Vivisection in Edwardian England. Madison: University of Wisconsin Press, 1985.

Leavitt, Emily Stewart. "The Evolution of Anti-Cruelty Laws in the United States." In Animals and Their Legal Rights, 2nd ed. Washington, D.C.: Animal Welfare Institute, 1970. 
Lederer, Susan E. "The Controversy Over Animal Experimentation in America, 1880-1914." In Vivisection in Historical Perspective, ed. Nicolaas A. Rupke. New York: Routledge, 1987.

Martinez, Jenny S. The Slave Trade and the Origins of International Human Rights Law. New York: Oxford University Press, 2012.

McCrea, Roswell C. The Humane Movement: A Descriptive Survey. New York: Columbia University Press, 1910.

McGirr, Lisa. The War on Alcohol: Prohibition and the Rise of the American State. New York: W.W. Norton \& Co., 2016.

McShane, Clay, and Joel A. Tarr. The Horse in the City: Living Machines in the Nineteenth Century. Baltimore: John Hopkins University Press, 2007.

Montgomery, David. Citizen Worker: The Experience of Workers in the United States with Democracy and the Free Market During the Nineteenth Century. New York: Cambridge University Press, 1993.

Morris, Thomas D. Southern Slavery and the Law, 1619-1860. Chapel Hill: University of North Carolina Press, 1996.

Moyn, Samuel. The Last Utopia: Human Rights in History. Cambridge, MA: Harvard University Press, 2010.

New York Times. 11 March 1866: 4.

Novak, William J. The People's Welfare: Law Eु Regulation in Nineteenth Century America. Chapel Hill: University of North Carolina Press, 1996.

Oliver, Wesley MacNeil. "The Modern History of Probable Cause.” Tennessee Law Review 78 (2010): $377-429$.

Pearson, Susan J. The Rights of the Defenseless: Protecting Animals and Children in Gilded Age America. Chicago: University of Chicago Press, 2011.

. "The Cow and the Plow: Animal Suffering, Human Guilt, and the Crime of Cruelty." In Toward a Critique of Guilt: Perspectives from Law and the Humanities, edited by Matthew Anderson. Oxford: Elsevier Ltd., 2005.

Pearson, Susan J. and Kimberly K. Smith. "Developing the Animal Welfare State." In Statebuilding from the Margins: Between Reconstruction and the New Deal, edited by Carol Nackenoff and Julie Novkov. Philadelphia: University of Pennsylvania Press, 2014.

Pleck, Elizabeth. "Criminal Approaches to Family Violence, 1640-1980." Crime and Justice 11 (1989): 19-57.

—. Domestic Tyranny: The Making of Social Policy Against Family Violence from Colonial Times to the Present. New York: Oxford University Press, 1987.

Quinlan, Oscar L. "Have Animals Rights?" Central Law Journal 38 (1894): 160-66.

Reeve, Tapping. The Law of Baron and Femme, of Parent and Child, of Guardian and Ward, of Master and Servant; and of the Powers of the Courts of Chancery. 3rd ed. Albany: William Gould, 1862.

Regan, Tom. The Case for Animal Rights. Berkeley: University of California Press, 1983.

Richards, Stewart. "Vicarious Suffering, Necessary Pain: Physiological Method in Late NineteenthCentury Britain." In Vivisection in Historical Perspective, edited by Nicolaas A. Rupke. New York: Routledge, 1987.

Ritvo, Harriet. The Animal Estate: The English and other Creatures in the Victorian Age. Cambridge: Harvard University Press, 1987.

Ryder, Richard D. Animal Revolution: Changing Attitudes Towards Speciesism. New York: B. Blackwell, 1989.

- The Political Animal: The Conquest of Speciesism. Jefferson, NC: McFarland \& Co., 1998.

Siegel, Reva B. “The Rule of Love': Wife Beating as Prerogative and Privacy." Yale Law Journal 105 (1996): 2122-207.

Singer, Peter. Animal Liberation. New York: Avon Books, 1990.

Steele, Zulma. Angel in a Top Hat. New York: Harper \& Brothers, 1942.

Stuntz, William J. "The Pathological Politics of Criminal Law." Michigan Law Review 100 (2001): $505-600$.

"The General Laws and Liberties of the Massachusetts Colony (1672)." In The Colonial Laws of Massachusetts. Boston: Rockwell \& Churchill, 1890.

Turner, E.S. All Heaven in a Rage. New York: St. Martin's Press, 1964. 
Turner, James. Reckoning with the Beast: Animals, Pain and Humanity in the Victorian Mind. Baltimore: Johns Hopkins University Press, 1980.

Tushnet, Mark V. Slave Law in the American South: State v. Mann in History and Literature. Lawrence: University Press of Kansas, 2003.

Vandervelde, Lea. "The Last Legally Beaten Servant in America: From Compulsion to Coercion in the American Workplace." Seattle University Law Review (2016): 727-85.

Walters, Ronald G. The Antislavery Appeal: American Abolitionism after 1830. Baltimore: Johns Hopkins University Press, 1976.

Wilson, Douglas L. Honor's Voice: The Transformation of Abraham Lincoln. New York: Alfred A. Knopf, 1998.

\section{CASES CITED}

Bradley v. State, 1 Miss. (1 Walker) 156 (1824).

Commonwealth v. Curry, 150 Mass. 509 (1890).

Commonwealth v. Flannigan, 137 Mass. 560 (1884).

Commonwealth v. Howes, 26 Pa.D. 610 (1917).

Commonwealth v. Lee \& Bledsoe, 60 Ky. 229 (1860).

Commonwealth v. Leach, 1 Mass. 59 (1804).

Commonwealth v. Lewis, 140 Pa. 261 (1891).

Commonwealth v. Lufkin, 89 Mass. 579 (1863).

Commonwealth v. McClellan, 101 Mass. 34 (1869).

Commonwealth v. Taylor, 5 Binn. 277.

Commonwealth v. Thornton, 113 Mass 457 (1873).

Commonwealth v. Tilton, 49 Mass. 232 (1844).

Commonwealth v. Turner, 26 Va. 678 (1827).

Commonwealth v. Turner, 145 Mass. 296 (1887).

Commonwealth v. Whitman, 118 Mass. 458 (1875).

Darnell v. State, 6 Tex. App. 482 (1879).

Davis v. Commonwealth, 30 Pa. 421 (1858).

Davis v. Society for Prevention of Cruelty, 16 Abb. Pr. (N.S.) 73 (New York Common Pleas 1874).

Davis v. American Society for the Prevention of Cruelty to Animals, 75 N.Y. 362 (1878).

Duncan v. State, 49 Miss. 331 (1873).

Fairfax Branch v. State, 41 Tex. 622 (1874).

Geuslh v. Mynns, Cro. Jac. 321.

Grise v. State, 37 Ark. 456 (1881).

Gundry v. Feltham, 1 T. R. 334.

Hodge v. State, 79 Tenn. 528 (1883).

James v. Carper, 36 Tenn. 397 (1857).

Johnson and Wife v. State, 21 Tenn. 229 (2 Hum. 283) (1837).

Kilpatrick v. People, 5 Denio 277 (1848).

King v. Tai Wa, 5 Haw. 596 (1886).

People v. Brunell, 48 How. Pr. 435 (1874).

People v. Smith, 5 Cow. 258 (1825).

People v. Tinsdale, 10 Abb. Pr.(N.S.) 374 (1868).

Pendergrass v. State, 19 N.C. 365 (1837).

Respublica v. Teischer, 1 U.S. 335 (1788).

Rose v. State, 1 Tex. App. 400 (1876).

State v. Allison, 90 N.C. 733 (1884).

State v. Avery, 44 N.H. 392 (1862).

State v. Beekman, 27 N.J.L. 124 (1858).

State v. Black, 60 N.C. (Win.) 262 (1864). 
State v. Bogardus, 4 Mo. App. 215 (1877).

State v. Bosworth, 4 A. 248 (1886).

State v. Butts, 92 N.C. 784 (1885).

State v. Brocker, 32 Tex. 611 (1870).

State v. Bruner, 12 N.E. 103 (1887).

State v. Gould, 26 W. Va. 258 (1885).

State v. Greenlees, 41 Ark. 353 (1883).

State v. Hackfath, 20 Mo. App. 614 (1886).

State v. Hale, 9 N.C. 582 (1823).

State v. Neal, 120 N.C. 613 (1897).

State v. Porter, 112 N.C. 887 (1893).

State v. Rhodes, 61 N.C. (Phil. Law) 453 (1868).

State v. Roche, 37 Mo. App. 480 (1889).

State v. Smith, 21 Tex. 748 (1848).

Tatum v. State, 66 Ala. 465 (1880).

The Stage Horse Cases, Broadway et. al. v. American Society for the Prevention of Cruelty to Animals, Christie v. Bergh, 15 Abb. Pr. (N.S.) 51 (1873).

Thomas v. State, 14 Tex. App. 200 (1883).

United States v. Jackson, 26 F. Cas. 555, 4 D.C. 483 (1834).

United States v. Logan, 26 F. Cas. 990, 2 D.C. 259 (1821).

Waters v. People, 23 Colo. 33 (1896).

Wilson v. State, 29 Tex. 240 (1867).

Wright v. Georgia, 30 Ga. 325 (1860).

\section{STATUTES CITED}

Laws of New York 1857, Vol. 2, Ch. 405.

N.Y. Rev. Stat. Tit. 6, 26 (1829). 